\title{
ALTERATION ASSEMBLAGES IN MARTIAN METEORITES: IMPLICATIONS FOR NEAR-SURFACE PROCESSES
}

\author{
J.C. BRIDGES ${ }^{1}$, D.C. CATLING ${ }^{2}$, J.M. SAXTON ${ }^{3}$, T.D. SWINDLE ${ }^{4}$, I.C. LYON $^{3}$ \\ and M.M. GRADY ${ }^{1}$ \\ ${ }^{1}$ Department of Mineralogy, Natural History Museum, London SW7 5BD, UK \\ ${ }^{2}$ SETI Institute/NASA Ames Research Center, Moffett Field, California, USA \\ ${ }^{3}$ Department of Earth Sciences, Manchester University, Manchester M13 9PL, UK \\ ${ }^{4}$ Lunar and Planetary Laboratory, University of Arizona, Tucson, Arizona 85721-0092, USA
}

Received: 8 August 2000; accepted: 16 February 2001

\begin{abstract}
The SNC (Shergotty-Nakhla-Chassigny) meteorites have recorded interactions between martian crustal fluids and the parent igneous rocks. The resultant secondary minerals - which comprise up to $\sim 1$ vol. $\%$ of the meteorites - provide information about the timing and nature of hydrous activity and atmospheric processes on Mars. We suggest that the most plausible models for secondary mineral formation involve the evaporation of low temperature $\left(25-150^{\circ} \mathrm{C}\right)$ brines. This is consistent with the simple mineralogy of these assemblages - Fe-Mg-Ca carbonates, anhydrite, gypsum, halite, clays - and the chemical fractionation of Ca-to Mg-rich carbonate in ALH84001 "rosettes". Longerlived, and higher temperature, hydrothermal systems would have caused more silicate alteration than is seen and probably more complex mineral assemblages. Experimental and phase equilibria data on carbonate compositions similar to those present in the SNCs imply low temperatures of formation with cooling taking place over a short period of time (e.g. days). The ALH84001 carbonate also probably shows the effects of partial vapourisation and dehydration related to an impact event postdating the initial precipitation. This shock event may have led to the formation of sulphide and some magnetite in the Fe-rich outer parts of the rosettes.

Radiometric dating ( $\mathrm{K}-\mathrm{Ar}, \mathrm{Rb}-\mathrm{Sr}$ ) of the secondary mineral assemblages in one of the nakhlites (Lafayette) suggests that they formed between 0 and $670 \mathrm{Myr}$, and certainly long after the crystallisation of the host igneous rocks. Crystallisation of ALH84001 carbonate took place 0.5 Gyr after the parent rock. These age ranges and the other research on these assemblages suggest that environmental conditions conducive to near-surface liquid water have been present on Mars periodically over the last $\sim 1$ Gyr. This fluid activity cannot have been continuous over geological time because in that case much more silicate alteration would have taken place in the meteorite parent rocks and the soluble salts would probably not have been preserved.

The secondary minerals could have been precipitated from brines with seawater-like composition, high bicarbonate contents and a weakly acidic nature. The co-existence of siderite (Fe-carbonate) and clays in the nakhlites suggests that the $\mathrm{pCO}_{2}$ level in equilibrium with the parent brine may have been 50 mbar or more. The brines could have originated as flood waters which percolated through the top few hundred meters of the crust, releasing cations from the surrounding parent rocks. The high sulphur and chlorine concentrations of the martian soil have most likely resulted from aeolian redistribution of such aqueously-deposited salts and from reaction of the martian surface with volcanic acid volatiles.

The volume of carbonates in meteorites provides a minimum crustal abundance and is equivalent to 50-250 mbar of $\mathrm{CO}_{2}$ being trapped in the uppermost 200-1000 $\mathrm{m}$ of the martian crust. Large fractionations in $\delta^{18} \mathrm{O}$ between igneous silicate in the meteorites and the secondary minerals $(\leq 30 \%$ ) require formation of the latter below temperatures at which silicate-carbonate equilibration could have taken place $\left(\sim 400^{\circ} \mathrm{C}\right)$ and have been taken to suggest low temperatures (e.g. $\left.\leq 150^{\circ} \mathrm{C}\right)$ of precipitation from a hydrous fluid.
\end{abstract}

Chronology and Evolution of Mars 365-392, 2001.

(C) 2001 Kluwer Academic Publishers. Printed in the Netherlands. 


\section{Introduction}

Secondary mineral assemblages have been characterised in 7 of the 16 SNC (Shergotty-Nakhla-Chassigny) meteorites (Table I). To date they have been found in the 3 nakhlites Nakhla, Governador Valadares, Lafayette (olivine clinopyroxenites); ALH84001 (orthopyroxenite); Shergotty, EETA79001 (basaltic shergottites) and Chassigny (dunite). It is possible that all of the SNCs contain the secondary assemblages but they have not yet been identified or terrestrial alteration has obscured their presence. In this paper we review the mineralogy, stable isotopes, radiometric dating, associated fluid compositions and different models for formation of the SNC secondary phases. Secondary minerals have the potential to reveal compositional and isotopic information about the ancient martian atmosphere and to constrain the nature of fluid processes at the martian surface.

Radiometric dating of the secondary assemblages and their host meteorites also may constrain the times in Mars history when a thicker atmosphere was present and conditions were more favourable for the existence of liquid water. Oxygen isotopic studies provide information about chemical and isotopic fractionation processes in both the martian atmosphere and the crustal fluids. Finally, one of the underlying motivations in the study of SNCs and their secondary phases has been the search for traces of extraterrestrial life.

A description of the different SNC silicate petrographies is given in the paper by Nyquist et al. (2001). The main secondary mineral phases are carbonates, sulphates, halite and clay minerals (the latter particularly in the 3 nakhlites) although associated sulphides and ferric oxides are also sometimes present. There is some limited evidence for the occurrence of nitrates (Grady et al., 1995). In addition, there are hydrous amphiboles associated with melt inclusions e.g. the kaersutite amphibole within Chassigny and the shergottites, that may have exchanged with or trapped martian surface water reservoirs (Treiman, 1985). Carbonate in ALH84001 occupies about 1 vol.\%, heterogeneously distributed, within the meteorite (Treiman, 1995). Similarly, the proportion of secondary mineral phases can reach 1-2\% in some sections of Nakhla (Bridges and Grady, 1999). Other SNCs have lower proportions of secondary minerals. Bulk meteorite water contents, associated with the secondary minerals range from $0.04 \mathrm{wt} \%$ in the shergottites to $0.4 \mathrm{wt} \%$ in the clay-rich nakhlites (Karlsson et al., 1992).

The secondary minerals in the nakhlites and ALH84001 are assumed to be martian from a combination of textural and isotopic information. For instance, clay veins within the nakhlites are truncated by fusion crust and so are clearly preterrestrial (Gooding et al., 1991; Treiman et al., 1993). The association of some of the ALH84001 carbonate with preterrestrial fracturing is also incompatible with a terrestrial origin (e.g. Mittlefehldt, 1994). D/H ratios in some mineral phases are too high to be of terrestrial origin (Watson et al., 1994, Leshin et al., 1996, Saxton et al., 2000a) and the highest values are comparable to values in the martian atmosphere. The $\mathrm{D} / \mathrm{H}$ ratio in the martian atmosphere is $(8.1 \pm 0.3) \times 10^{-4}$ (i.e. $\delta \mathrm{D}$ 
TABLE I

Summary of secondary and hydrous mineral assemblages in SNC meteorites

\begin{tabular}{|c|c|c|c|c|c|}
\hline $\begin{array}{l}\text { Meteorite } \\
\text { (type) }\end{array}$ & $\begin{array}{l}\text { Mineral } \\
\text { assemblage }\end{array}$ & $\begin{array}{l}\text { Carbonate } \\
\text { composition } \\
(\mathrm{mol} \%)\end{array}$ & Main textures & Other analyses & Interpretations \\
\hline $\begin{array}{l}\text { Lafayette } \\
\text { (nakhlite, } \\
\text { find) }\end{array}$ & $\begin{array}{l}\text { clay, sd, po, fh, } \\
\operatorname{gyp}(1,2,3,4)\end{array}$ & $\begin{array}{l}\operatorname{cc} 22-37 \text { rh4-35 } \\
\text { mg0-2 sd27-67 } \\
\text { (4) }\end{array}$ & $\begin{array}{l}\text { sd + clay within } \\
\text { fractured ol } \\
\text { (iddingsite) (4). } \\
\text { Carbonate } \\
\text { grains }<50 \mu \mathrm{m} .\end{array}$ & $\begin{array}{l}\text { K-Ar age (5), O- } \\
\text { isotopes }(3,6,7,8) \text {, } \\
\text { C-isotopes (7), S- } \\
\text { isotopes, (9) TEM } \\
\text { smectite (2), trace } \\
\text { elements } \\
\text { LREE>HREE (4). }\end{array}$ & $\begin{array}{l}\text { Low-T fluids (2), } \\
\text { evaporitic, related to } \\
\text { other nakhlites (4). }\end{array}$ \\
\hline $\begin{array}{l}\text { Governador } \\
\text { Valadares } \\
\text { (nakhlite, } \\
\text { find) }\end{array}$ & clay, sd, gyp (4) & $\begin{array}{l}\mathrm{cc} 4-11 \text { rh1-2 } \\
\mathrm{mg} 9-29 \text { sd64- } \\
78(4)\end{array}$ & $\begin{array}{l}\text { clay veins within } \\
\text { ol (iddingsite), } \\
\text { sd + gyp } \\
\text { interstitial (4). }\end{array}$ & $\begin{array}{l}\text { S-isotopes (9), C- } \\
\text { isotopes (1), } \\
\text { trace elements } \\
\text { LREE>HREE (4). }\end{array}$ & $\begin{array}{l}\text { Evaporitic, related to } \\
\text { other nakhlites (4). }\end{array}$ \\
\hline $\begin{array}{l}\text { Nakhla } \\
\text { (nakhlite, } \\
\text { fall) }\end{array}$ & $\begin{array}{l}\text { clay, sd, gyp, } \\
\text { an, hal, ep, go } \\
(1,4,10,11)\end{array}$ & $\begin{array}{l}\mathrm{cc} 0-6 \text { rh } 1-40 \\
\mathrm{mg} 2-41 \mathrm{sd} 23- \\
87(4)\end{array}$ & $\begin{array}{l}\text { Clay veins truncated } \\
\text { by fusion crust (10), } \\
\text { clay, gyp veins } \\
\text { within ol } \\
\text { (iddingsite), sd + } \\
\text { anh + hal mainly } \\
\text { interstitial (11). }\end{array}$ & $\begin{array}{l}\text { Trace elements } \\
\text { LREE>HREE } \\
(4,11), \text { D/H of } \\
\text { carbonate }(12), \text { O- } \\
\text { isotopes }(7,8,12 \text {, } \\
\text { 13), C-isotopes } \\
(7,13,14), \text { S-isotopes } \\
\text { (9), TEM smectite (1). }\end{array}$ & $\begin{array}{l}\text { Liquid water in parent } \\
\text { rocks } \\
\text { (1), evaporitic, related } \\
\text { to other nakhlites (4), } \\
\text { hydrothermal } \\
\text { sulphides (9). }\end{array}$ \\
\hline $\begin{array}{l}\text { Chassigny } \\
\text { (chassignite, } \\
\text { fall) }\end{array}$ & $\begin{array}{l}\text { cc, mg, gyp } \\
(15), \\
\text { amphiboles } \\
\text { (kaersutite) in } \\
\text { melt inclusions (16) }\end{array}$ & & $\begin{array}{l}\text { Discontinuous veins } \\
\text { (of clay?) within ol. } \\
\text { Amphiboles in melt } \\
\text { inclusions suggest } \\
\text { some water } \\
\text { in melt (16). }\end{array}$ & $\begin{array}{l}\text { D/H of amphiboles } \\
\text { and biotite (17), S- } \\
\text { isotopes (9). }\end{array}$ & Salts from brine (15). \\
\hline $\begin{array}{l}\text { Shergotty } \\
\text { (shergottite, } \\
\text { fall) }\end{array}$ & $\begin{array}{l}\text { gyp, hal, other } \\
\text { chlorides, } \\
\text { sulphates, } \\
\text { phyllosilicates (18) } \\
\text { amphiboles in } \\
\text { melt inclusions (19) }\end{array}$ & & $\begin{array}{l}\text { Salts on } \\
\text { fracture } \\
\text { surfaces and } \\
\text { veins. Melt } \\
\text { undersaturated } \\
\text { in water (19). }\end{array}$ & $\begin{array}{l}\mathrm{D} / \mathrm{H} \text { of amphiboles } \\
\text { (17). }\end{array}$ & $\begin{array}{l}\text { Episodic weathering } \\
\text { (18). } \\
\text { Extraterrestrial origin } \\
\text { less firmly established } \\
\text { for shergottites than } \\
\text { nakhlites, ALH84001. }\end{array}$ \\
\hline $\begin{array}{l}\text { EETA79001 } \\
\text { (shergottite, } \\
\text { find) }\end{array}$ & $\begin{array}{l}\mathrm{cc}, \operatorname{gyp}(?)(20), \\
\text { amphibole in } \\
\text { melt inclusions (21) }\end{array}$ & & $\begin{array}{l}\text { Present as druse } \\
\text { vug fillings in } \\
\text { lithology } C \text { glass. }\end{array}$ & $\begin{array}{l}\mathrm{O}, \mathrm{C}, \mathrm{N} \text { isotopes of } \\
\text { druse }(22,23,24) .\end{array}$ & $\begin{array}{l}\text { Weathering followed } \\
\text { by shock } \\
\text { implantation (20). }\end{array}$ \\
\hline $\begin{array}{l}\text { ALH84001 } \\
\text { (orthopyroxe } \\
\text { nite, find) }\end{array}$ & $\begin{array}{l}\text { ank, mica, pyr, } \\
\text { Fe-sulph, mag, } \\
\text { silica }\end{array}$ & $\begin{array}{l}\text { average cc11.5 } \\
\text { rh1.1 mg58.0, } \\
\text { sd29.4 (25); } \\
\text { zoned core from } \\
\text { cc to mg end } \\
\text { members (26) }\end{array}$ & $\begin{array}{l}\text { Crack fillings and } \\
\text { globules/rosettes } \\
(<250 \mu \mathrm{m}) \text { in } \\
\text { interstitial areas } \\
\text { with maskelynite. }\end{array}$ & $\begin{array}{l}\mathrm{O}, \mathrm{C} \text { isotopes ( } 27- \\
\text { 32), } \\
\text { carbonate has LREE } \\
\leq \text { HREE (33), } \\
\text { carbonate age (Rb- } \\
\mathrm{Sr}, \mathrm{U}-\mathrm{Th}-\mathrm{Pb})(34) \text {, } \\
\text { D/H (35). }\end{array}$ & $\begin{array}{l}\text { Evaporitic (36), } \\
\text { hydrothermal, (25,37), } \\
\text { impact meta- } \\
\text { somatism (26), impact } \\
\text { remelting/ } \\
\text { remobilisation } \\
\text { (38), biogenic (39). }\end{array}$ \\
\hline $\begin{array}{l}\text { LEW88516 } \\
\text { (shergottite, } \\
\text { find) }\end{array}$ & $\begin{array}{l}\text { amphibole in } \\
\text { melt inclusions(21) }\end{array}$ & & & & \\
\hline $\begin{array}{l}\text { Zagami } \\
\text { shergottite, } \\
\text { fall) }\end{array}$ & & & & $\begin{array}{l}\text { D/H of apatite (17), } \\
\text { O-isotopes (27). }\end{array}$ & \\
\hline
\end{tabular}

an anhydrite, cc calcite, ep epsomite, fh ferrihydrite, go goethite, gyp gypsum, hal halite, mag magnetite, mg magnesite, ol olivine, po unidentified 'porous oxide', rh rhodochrosite, sd siderite. 1. Reid and Bunch (1975), 2. Treiman et al. (1993), 3. Vicenzi and Eiler (1998), 4. Bridges and Grady (2000), 5. Swindle et al. (2000), 6. Romanek et al. (1998), 7. Wright et al. (1992), 8. Farquhar and Thiemens (2000), 9. Greenwood et al. (2000), 10. Gooding et al. (1991), 11. Bridges and Grady (1999), 12. Saxton et al. (2000b), 13. Jull et al. (1995), 14. Carr et al. (1985), 15. Wentworth and Gooding (1994), 16. Floran et al. (1978), 17. Watson et al. (1994), 18. Wentworth and Gooding (2000), 19. Treiman (1985), 20. Gooding et al. (1988), 21. Treiman (1998b), 22. Clayton and Mayeda (1988), 23. Wright et al. (1988), 24. Douglas et al. (1994), 25. Mittlefehldt (1994), 26. Harvey and McSween (1996), 27. Jull et al. (1997), 28. Saxton et al. (1998), 29. Leshin et al. (1998), 30. Farquhar et al. (1998), 31. Valley et al. (1997), 32. Romanek et al. (1994), 33. Wadhwa and Crozaz (1995), 34. Borg et al. (1999), 35. Sugiura and Hoshino (2000), 36. Warren (1998), 37. Kring et al. (1998), 38. Scott (1999), 39. McKay et al. (1996). 
$=4200 \%$ ) , which is about 5.2 times the ratio of $1.6 \times 10^{-4}$ for terrestrial seawater (Owen, 1992). These meteorites also contain phases whose carbon (Romanek et al., 1994), sulphur and oxygen isotopes (Farquhar et al., 1998, 2000; Farquhar and Thiemens, 2000) are inconsistent with a terrestrial origin. Finally, as we will discuss later, the radiometric ages determined on some of the secondary mineral assemblages must predate the meteorites' residence times on Earth. However, the evidence used to establish a martian origin for the secondary mineral assemblages in the nakhlites and ALH84001 has not yet been as conclusively demonstrated for the other SNCs. Terrestrial salts can be present and are abundant in the desert finds Dar al Gani 476 and 489 (Wadhwa et al., 2000). Minor efflorescence of salt from meteorite interiors onto the fusion crusts can also occur (Gooding et al., 1991) and so care is necessary in distinguishing martian from terrestrial mineral assemblages. Isotopic data suggests that some of the shergottites may contain traces of terrestrial salts along with martian secondary assemblages. Therefore, we concentrate on the information obtained from the nakhlites and ALH84001.

\section{Research on Secondary Minerals in SNCs and Models for Their Formation}

The first description of extraterrestrial alteration assemblages in these meteorites was made by Reid and Bunch (1975) who described fibrous material ("iddingsite") associated with olivine grains within Nakhla. On the basis of a TEM study, Gooding et al. (1991) noted that the iddingsite veins within Nakhla olivine contained a probable smectite/illite, K-bearing mixed layer clay. Similarly, Treiman et al. (1993) described smectite in Lafayette. Carbonate and sulphate minerals were first identified within the EETA79001 martian meteorite (Gooding et al., 1988) although their presence had earlier been inferred through pyrolysis or stepped combustion experiments (Carr et al., 1985; Gooding and Muenow, 1986).

Subsequent studies (summarised in Table I) have enabled the mineralogical and stable isotope characteristics to be understood in more detail. The three nakhlites (Lafayette, Governador Valadares and Nakhla) contain smectite/illite, siderite, sulphates and halite (Chatzitheodoridis and Turner, 1990; Gooding et al., 1991; Treiman et al., 1993; Bridges and Grady, 1999, 2000). The clay veins in these meteorites cross-cut the olivine and, in Lafayette (Figure 1a), they are intergrown with Ca-rich siderite (Vicenzi and Eiler, 1998; Bridges and Grady, 2000). In contrast most of the siderite in Governador Valadares and Nakhla is located in interstitial positions and has lower Ca contents. These two meteorites contain gypsum, Nakhla also containing anhydrite (Chatzitheodoridis and Turner, 1990; Bridges and Grady, 1999), halite and epsomite (Gooding et al., 1991). Figure 1b shows halite and anhydrite within a section of Nakhla. Chassigny contains calcite, $\mathrm{Mg}$-carbonate and gypsum (Wentworth and Gooding, 1994) in veins within the silicate minerals. Shergotty has sulphate and halite with minor phyllosilicates (Gooding et al., 

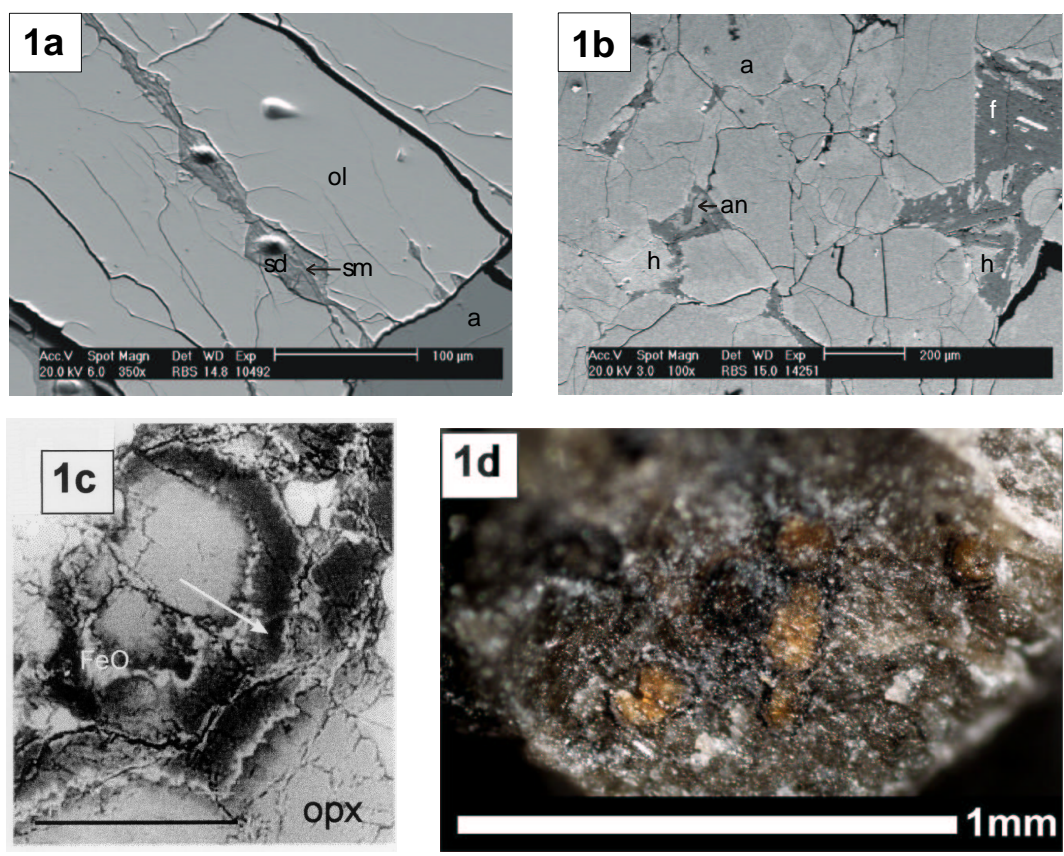

Figure 1. a) Back-scattered electron image of "iddingsite" alteration of olivine in the nakhlite Lafayette. The alteration assemblage consists of siderite and smectite along fractures. The smectite clay is found in the centres of the fractures (arrowed). The two spots in the fractures are ion probe analysis points (Bridges and Grady, 2000). b) Back-scattered electron image of salt minerals in Nakhla, where they mainly occupy interstitial areas. ol olivine, sd siderite, sm smectite, a cumulus augite, $\mathrm{h}$ halite, an anhydrite, f intergown feldspar, feldspathic glass and silica polymorphs. c) Backscattered electron image of carbonate rosette in ALH84001. Carbonate, with increasing $\mathrm{Mg} / \mathrm{Ca}$ ratio towards rim (arrowed). The white circular area $(\mathrm{FeO})$ within the carbonate is a mixture of iron oxide (magnetite) and iron sulphide. opx orthopyroxene. Scale bar $100 \mu \mathrm{m}$. d) Carbonate 'rosettes' exposed on split surface of ALH84001 meteorite. The rounded, yellowish brown carbonate grains have dark, magnetite-rich rims. The surrounding meteorite is mainly composed of orthopyroxene grains.

1988; Treiman, 1985; Wentworth and Gooding, 2000) in fractures. The shergottite EETA79001 contains calcite and sulphate but located within druse cavities in the glassy parts of that meteorite (Gooding et al., 1988).

ALH84001 has the most abundant carbonate and the largest grains or "rosettes" ( $\leq 250 \mu \mathrm{m}$, Figure 1c, d). The average composition of the carbonate (Figure 2) is cc $11.5 \mathrm{rh} 1.1 \mathrm{mg} 58.0 \mathrm{sd} 29.4 \mathrm{~mol} . \%$ and the "rosettes" are zoned from Ca-rich cores to Fe- and, on their outsides, Mg-rich (nearly pure magnesite) rims (Mittlefehldt, 1994; Harvey and McSween, 1996). Magnetite and Fe-sulphides (including pyrrhotite) are associated with the Fe-rich domains (McKay et al., 1996). Minor phyllosilicate and silica veins are located in isolated pyroxene grain fractures, more extensive fracture zones in the meteorite, interstitial sites beside plagioclase shock glass and occasionally with carbonate (e.g. Mittlefehldt, 1994; Scott, 1999; Brearley, 2000). 


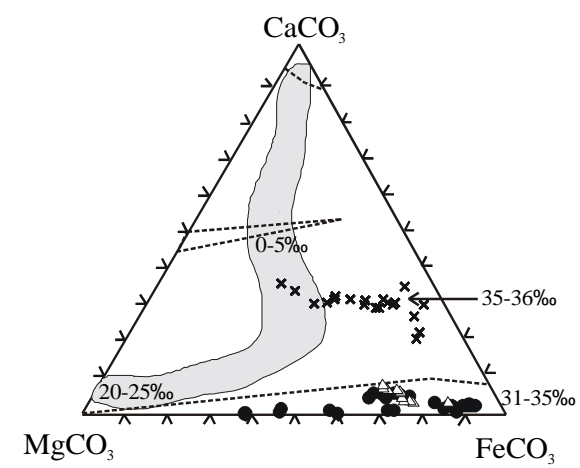

Figure 2. Fields for carbonate (mol \%) compositions in ALH84001 (grey field) and the 3 nakhlites Lafayette (crosses), Governador Valadares (triangles) and Nakhla (circles). The order of decreasing Ca-carbonate contents between the nakhlites is Lafayette $>$ Governador Valadares $>$ Nakhla. Also shown in dashed areas are the one-phase solid solution fields for this system at $550{ }^{\circ} \mathrm{C}$ (Anovitz and Essene, 1987). With decreasing temperature the size of these fields decreases. The Lafayette and ALH84001 compositions are metastable. Further carbonate compositions are given in Bridges and Grady (2000). The correlation of $\delta^{18} \mathrm{O}$ enrichment with Mg contents in ALH84001 carbonate is shown with isotopic values beside the chemical compositions. Carbonate data from Harvey and McSween (1996) and Bridges and Grady (1999, 2000). Oxygen isotope data from Leshin et al. (1998), Saxton et al. (1998), Vicenzi and Eiler (1998).

The first isotopic analyses of secondary minerals in SNCs were obtained through the stepped combustion experiments (Carr et al., 1985). Analysis of EETA79001 suggested the possibility of two components of ${ }^{13} \mathrm{C}$-enriched carbon, one from carbonate, the second with $\delta^{13} \mathrm{C} \sim+36 \%$, from trapped martian atmospheric $\mathrm{CO}_{2}$. Similarly, heavy $\mathrm{N}$ and $\mathrm{O}$ isotopic components and $\mathrm{D} / \mathrm{H}$ enrichments have been described in components of martian meteorites (e.g. Wright et al., 1988; Clayton and Mayeda, 1988; Watson et al., 1994). These isotopic features have also been tentatively related to martian atmospheric compositions and some (heavy $\mathrm{C}, \mathrm{O}$ isotopes) have been shown to be carried by secondary minerals.

Three main models to explain the formation of the mineral assemblages have been proposed: formation from (1) brines, (2) shock processes, and (3) hydrothermal processes. Each may explain some of the features seen in the meteorites. The general nature of the mineral assemblages in the SNCs - consisting largely of carbonate, sulphate, clay and chloride - suggests a link with brines and evaporite formation. However, there is also evidence for an association with shock remobilisation, particularly in ALH84001 (e.g. Scott et al., 1997) and possibly EETA79001 (Gooding et al., 1988). It has also been suggested that hydrothermal processes (by which we mean fluid activity at relatively high temperatures $>150^{\circ} \mathrm{C}$, compared to those of groundwater), may also have left traces within the meteorites (e.g. Greenwood et al., 2000). In the following subsections we attempt to summarise the supporting evidence for the main models, review evidence for martian biogenic traces in ALH84001, and suggest which of the mineralogical features may be most readily explained by each of the models. 


\subsection{Experimental Constraints On SNC SECONDARy Mineral STABILITIES}

Experimental studies designed to constrain the formation conditions of carbonatebearing assemblages in SNCs have shown that they could have formed over a period of a few days from mixed $\mathrm{CO}_{2}-\mathrm{H}_{2} \mathrm{O}$ fluids interacting with basaltic rock at low temperatures (Baker et al., 2000). This work demonstrated that none of the SNC meteorites need have undergone protracted interaction with aqueous fluids. In a separate set of experiments Golden et al. (2000) analysed the products precipitated from $\mathrm{Ca}-\mathrm{Mg}-\mathrm{Fe}-\mathrm{CO}_{2}-\mathrm{H}_{2} \mathrm{O}-\mathrm{Cl}$ solutions at various temperatures. They showed that carbonate globules, similar in terms of chemical zonation and size to those of ALH84001, could be formed at $150{ }^{\circ} \mathrm{C}$ whereas at $25^{\circ} \mathrm{C}$ amorphous Fe-rich carbonate formed after $24 \mathrm{~h}$ and more $\mathrm{Mg}$-rich carbonate after $96 \mathrm{~h}$.

Experimental studies on phase equilibria in the $\mathrm{CaCO}_{3}-\mathrm{MgCO}_{3}-\mathrm{FeCO}_{3}$ system (Anovitz and Essene, 1987) suggest that the Ca-Fe-rich carbonates of Lafayette (Bridges and Grady, 2000) and ALH84001 (Mittlefehldt, 1994; Harvey and McSween, 1996) are metastable i.e. if they had crystallised slowly then different, stable assemblages would have formed. The phase equilibria and experimental constraints point towards fairly low temperature $\left(\leq 150^{\circ} \mathrm{C}\right)$ precipitation of the original carbonate-bearing assemblages in SNCs over short periods of time (days).

\subsection{EVAPORATION AND EVAPORITES ON MARS}

The martian soil is thought to be composed of weathered rock (basalt to andesite) with a lesser Mg-rich component that may be associated with the salts, which are otherwise principally $\mathrm{S}, \mathrm{Cl}, \mathrm{Br}, \mathrm{K}, \mathrm{Na}$ (Bell et al., 2000). The Viking and Pathfinder landing sites showed signs of salt hardpans and Christensen and Moore (1992) suggested, on the basis of thermal inertia, albedo and radar measurements, that large areas of the martian soil were partially cemented by salts. This has helped prompt speculation about whether evaporite deposits exist on Mars. Craters have preserved possible evidence for saltpan formation resulting from an enclosed drainage pattern. Some of the most detailed characterisation of an area where such deposits could have formed has been done on an unnamed, $35 \mathrm{~km}$ diameter, crater within the Memnonia region of the ancient highlands (Forsythe and Zimbelman, 1995) which has well marked terracing consistent with the past presence of ponded water. Similarly, high albedo patches identified in photographs of the martian surface (e.g. "White Rock" near the Schiaparelli crater and other areas in the Valles Marineris system) have been interpreted as relict evaporites (Russell et al., 1999).

However, evaporite layers have not been positively identified with the Thermal Emission Spectrometer (TES) on the Mars Global Surveyor either at "White Rock" or elsewhere (Ruff et al., 2000). It is possible the perceived absence reflects the constraints of pixel and spectral resolution for the current TES (Moersch et al., 2000). In any case, there is little doubt that floodwaters and groundwater flow (Carr, 1996; Baker et al., 1992 have been important processes, at least intermittently, in 
shaping the channels which dissect much of the martian surface. When such water pooled at the ends of valleys or melted into channels, plains, or fissures, salts must have precipitated in the terminal phases by solute concentration from evaporation or freezing. Forsythe and Blackwelder (1998) described 144 craters in the ancient highlands which had enclosed drainage where water would have ponded.

Results from the MOC camera have shown that surface water may have flowed intermittently on Mars in geologically recent times, creating gullies (Malin and Edgett, 2000a; Hartmann, 2001). Concentrated brines are able to exist in a liquid state at temperatures of down to $-63{ }^{\circ} \mathrm{C}$ (Brass, 1980), and as mean surface temperatures on Mars are typically in the range $-33^{\circ} \mathrm{C}$ to $-68^{\circ} \mathrm{C}$ between $60^{\circ} \mathrm{N}$ and $60^{\circ} \mathrm{S}$, it seems likely that brines are associated with these features.

Brines in SNCs and floodwater models: The evaporite mineral assemblages of the 3 nakhlite meteorites have been modelled as products of brine evaporation by Bridges and Grady (2000). The similarity in cosmic ray exposure ages, crystallisation ages and silicate petrographies suggests that the 3 nakhlites were derived from the same source region on Mars, and so their secondary mineral assemblages may share a common origin. Lafayette contains minerals (Ca-rich siderite, clay) which in the model were derived from a relatively low extent (25\% brine remaining) of evaporation from a brine; Governador Valadares with siderite, gypsum and clay (20\%); Nakhla - which also contains anhydrite and halite - trapped the final products of evaporation through the nakhlite parent rocks $(<10 \%)$. The trace element abundances (Zr, Y, LREE > HREE) of the individual mineral grains reflect the dissolution of LREE-enriched mesostasis by the brine. Vicenzi and Eiler (1998) also noted the presence of distinct mineral phases and intricate banding within the Lafayette alteration assemblages.

Warren (1998) proposed that the carbonates in ALH84001 could have formed as a calcrete, where groundwater was saturated with carbonate concentrated through evaporation. Alternatively, the parent rock could have been covered by a deep layer of floodwater, with evaporation and percolation of the water leading to carbonate precipitation. The parent rocks were only briefly exposed to the envisaged floodwaters due to rapid groundwater flow or evaporation. This scenario would explain the lack of extensive alteration of the silicate phases.

Evaporation models also have the advantage of being consistent with the experimental constraints described above, especially for the siderite. The presence of gypsum e.g. in the nakhlite Governador Valadares also implies temperatures $<100^{\circ} \mathrm{C}$. However, if ALH84001 salts are evaporitic in origin, one may have to invoke physical mechanisms such as the occlusion of pore spaces (McSween and Harvey, 1998) or water stratification (Warren, 1998) to account for the absence of other salts, notably sulphates. Alternatively, the most soluble salts might have been leached on Mars if ALH84001 was not isolated from subsequent aqueous activity. Leaching of highly soluble halides or sulphate during the meteorite's residence in Antarctica is also possible. The process of evaporation related to brine evolution is considered in more detail in a later section. 


\subsection{High Temperature: SHOCK REMOBILISATION AND HYDROTHERMAL/CO ${ }_{2}$-CHARGED FLUIDS}

All of the SNC meteorites show some of the signs of having experienced high levels of shock (e.g. $30-45 \mathrm{GPa}$ for the shergottites, Stöffler et al., 1986). These signs include melt pockets, deformation features in the silicate minerals and the presence of maskelynite. Gooding et al. (1988) suggested that the salts within the "lithology C" of EETA79001, which is largely composed of shock melt, might have been entrained from the martian surface into the parent rock during the impact melting event. Evaporite sediments might have been assimilated into the cooling Nakhla parent lava (Bridges and Grady, 1999), although subsequently a direct evaporation model, described in the previous section, was found to be more consistent with the mineralogical features in the 3 nakhlites (Bridges and Grady, 2000).

Harvey and McSween (1996) argued that the carbonates in ALH84001 formed through rapid reaction between a $\mathrm{CO}_{2}$-rich, $\mathrm{H}_{2} \mathrm{O}$-poor fluid and the parent rock at $>650^{\circ} \mathrm{C}$. Subsequently, Kring et al. (1998) suggested that $\mathrm{CO}_{2}$-charged fluids at $<300{ }^{\circ} \mathrm{C}$ had been active in the ALH84001 parent rock for at least a few years. This timescale was based on predicted dissolution rates of plagioclase, with replacement by carbonate, in alkaline fluids. However, as we argue in this paper, the fluids associated with ALH84001 and the nakhlites were probably acidic so this relatively long time scale for fluid activity may be inaccurate. Models involving $\mathrm{CO}_{2}$-rich, $\mathrm{H}_{2} \mathrm{O}$-poor fluids do have the advantage of explaining the low abundance of hydrous minerals in ALH84001 compared to the nakhlites. However some phlogopitic mica intergrown with carbonate has since been described in ALH84001 (Brearley, 2000). Brearley suggested that the phlogopite was derived through the breakdown of pre-existing clay during shock heating at $<500{ }^{\circ} \mathrm{C}$. Treiman (1998a) documented fracturing episodes within ALH84001 and proposed that the carbonate had experienced 4 discrete deformation events. Bradley et al. (1998) also carefully documented the magnetite structures around the carbonate rosettes and suggested that whisker-shaped grains they found were most consistent with precipitation at high temperatures $\left(500-800^{\circ} \mathrm{C}\right)$ from a vapour. This was taken by Scott (1999) to be a result of the shock remobilisation of pre-existing carbonates and resultant break down of Fe-carbonate to a magnetite-bearing assemblage. However, the origin of the magnetite still remains controversial because some of the grains with euhedral outlines have also been suggested by other authors to be biological in origin (see next section). High temperature processes may partly explain the dehydrated nature of ALH84001 but they leave open the question of the initial origin of the salt minerals, prior to the shock event. Scott (1999) and Warren (1998) proposed that they might have been deposited during intermittent floods.

Greenwood et al. (2000) suggested that the nakhlites had undergone hydrothermal alteration during cooling of the igneous assemblage. This was based on the observed fractionation of $\delta^{34} \mathrm{~S}$ between the 3 meteorites (see section on stable isotopes) which was considered to be too great for low temperature processes. 
However as Farquhar and Thiemens (2000) subsequently demonstrated, fractionation of the $\mathrm{S}$ isotopes through photolysis probably occurred in the martian atmosphere. Therefore, a high temperature origin is not required to explain the $\mathrm{S}$ isotopic variations in the SNCs.

Warren (1998) noted some critical problems with hydrothermal models such as that proposed in the initial description of carbonates in ALH84001 by Mittlefehldt (1994) who suggested a temperature of $700{ }^{\circ} \mathrm{C}$. Hydrothermal systems on earth typically last for tens of thousands of years. This is implausible for the SNCs because the silicate minerals, especially in ALH84001, are relatively unaltered. The simple salt and clay mineral assemblages are not consistent with highly differentiated fluids which evolved over time. The chemical zonation preserved in the "rosettes" would have homogenised if it had been held at elevated temperatures for any protracted ( $>$ days) time (Treiman, 1998a). Another argument put against high temperature models is that the oxygen isotope compositions of silicate and carbonate are not in equilibrium (Farquhar et al., 1998; Romanek et al., 1994). If the carbonate is of high temperature origin then the oxygen isotopic disequilibrium could only be explained as a result of very rapid crystallisation. Temperature constraints based on oxygen isotopes are considered further in a later section.

\subsection{Suggested Relic Biological Activity in ALH84001}

McKay et al. (1996) suggested that the carbonate-magnetite-sulphide rosettes in ALH84001 were of martian, biogenic origin (for a further discussion see Nyquist et al., 2001). This provocative idea stimulated much interest in martian meteorites and the search for traces of life on Mars. Two of the main lines of evidence put forward by McKay et al. were the morphology of the magnetite and the presence of rod-like structures resembling fossil bacteria on carbonate surfaces.

The current balance of evidence does not strongly support the biogenic theory of origin for ALH84001 carbonates (Scott, 1999; Steele et al., 2000; Farquhar and Thiemens, 2000; Kathie et al., 2000; Bradley et al., 1998; Farquhar and Thiemens, 2000). The best argument for a biological origin rests with the morphology of some of the magnetite grains. However, the association which McKay et al. made for the carbonates with low temperature precipitation from aqueous fluids remains valid even if the process was not directly linked to biological activity.

\section{Stable Isotopes}

Stable isotope ratios $(\mathrm{O}, \mathrm{H}, \mathrm{C}, \mathrm{S}$ determined for the secondary minerals offer insights into formation conditions, fluid reservoirs and the evolution of the martian atmosphere. On the Earth, oxygen isotope ratios are frequently used to derive formation temperatures or to study mass-dependent fractionation of the isotopes between fluids and minerals. Accordingly, large fractionations in $\delta^{18} \mathrm{O}$ compositions of the secondary minerals in martian samples may indicate low temperature 
precipitation. In most natural (especially geological) processes, oxygen isotopes exhibit this mass-dependent fractionation, in which $\Delta^{17} \mathrm{O}=\delta^{17} \mathrm{O}-0.52 \delta^{18} \mathrm{O}=$ constant, but the SNCs contain evidence for mass-independent fractionation, with $\Delta^{17} \mathrm{O}$ varying between different phases in the same rock. Atmospheric loss can also fractionate stable isotopes: for instance, in the current martian atmosphere, $\mathrm{H}$ and $\mathrm{N}$ are enriched in their heavy isotopes (see Bogard et al., 2001, for a review).

\subsection{OXYGEN}

The carbonate data in ALH84001 reflect the fractionation of fluid composition, with progressively increasing $\mathrm{Mg} / \mathrm{Ca}$ ratios and $\delta^{18} \mathrm{O}$, and the temperature of carbonate precipitation. Three independent ion probe studies (Valley et al., 1997; Saxton et al., 1998; Leshin et al., 1998) show that the large range of cation chemistry is accompanied by a correspondingly large $(20-25 \%)$ variation in $\delta^{18} \mathrm{O}$. The isotopically heaviest carbonate $\left(\delta^{18} \mathrm{O}=+20-25 \%\right)$ is the Mg-rich rims. The lowest carbonate $\delta^{18} \mathrm{O}$ found by Leshin et al. (1998) was $\sim 5 \%$, but isotopically lighter $\left(\delta^{18} \mathrm{O} \geq-10 \%\right.$ ) , Ca-rich carbonate has been reported in ALH84001 by Saxton et al. (1998), Holland et al. (2000) and Eiler et al. (1998). The relationship of carbonate $\mathrm{Mg} / \mathrm{Ca}$ composition to $\delta^{18} \mathrm{O}$ for ALH84001 is shown on Figure 2.

Ion probe measurements of $\delta^{18} \mathrm{O}$ have also been made on siderite in two nakhlites, Nakhla (Saxton et al., 1998, 2000a) and Lafayette (Vicenzi and Eiler, 1998). The results are indistinguishable within error, both showing great enrichments in $\delta^{18} \mathrm{O}$ : Nakhla 4 grains, $+31-35 \%$; Lafayette, 2 grains, +35 and $+36 \%$.

Farquhar and Thiemens (2000) determined $\Delta^{17} \mathrm{O}$ of secondary phases and water in ALH84001, Nakhla and Lafayette through acid extraction and fluorination. They found that $\Delta^{17} \mathrm{O}$ of carbonate, sulphate and water released exceeded that of the silicate by up to $+1.3 \%$, demonstrating the lack of equilibrium between products of the martian hydrosphere and martian silicate. Martian silicate itself has $\Delta^{17} \mathrm{O}=+0.3 \%$ o compared to the terrestrial fractionation line (Franchi et al., 1999). The data of Farquhar and Thiemens is similar to that of Karlsson et al. (1992) who showed that water in the SNC meteorites had $\Delta^{17} \mathrm{O}$ greater than that of the anhydrous silicates by values up to $\Delta^{17} \mathrm{O}=+0.6 \%$ (Nakhla) although Shergotty and EETA 79001 showed no $\Delta^{17} \mathrm{O}$ excesses over their whole rock values.

Temperature and isotopic fractionation constraints from oxygen: Carbonate equilibrated with silicate at $500-700{ }^{\circ} \mathrm{C}$ would have $\delta^{18} \mathrm{O}$ compositions $2-3 \%$ higher than the silicate $(\sim+4 \%)$ and $\Delta^{17} \mathrm{O}$ equal to the silicate. Thus, the $\delta^{18} \mathrm{O}$ values determined for most of the carbonates are too high to represent equilibrium at igneous temperatures with the silicates, and so formation from an aqueous fluid has been considered. Here we outline the models used to constrain fluid temperatures.

A common starting point for consideration of carbonate oxygen isotope data (Clayton and Mayeda, 1988; Wright et al., 1992; Romanek et al., 1994; Saxton et al., 1998, 2000b) has been to consider water (or a water- $\mathrm{CO}_{2}$ mixture) equi- 
librated with the silicate at high temperature (at which isotopic fractionation is small), and then cooled. This process can be viewed on either a global (producing an atmosphere and hydrosphere) or local scale. In the case of a water- $\mathrm{CO}_{2}$ mixture, the final composition of the water depends on the temperature and $\mathrm{CO}_{2}: \mathrm{H}_{2} \mathrm{O}$ ratio; assuming $T=0{ }^{\circ} \mathrm{C}$, Clayton and Mayeda (1988) give $\delta^{18} \mathrm{O}_{\mathrm{H}_{2} \mathrm{O}}(\% o)=44.0 X-37.6$, where $X$ is the molar fraction of oxygen present as water. In this model, the water has the same $\Delta^{17} \mathrm{O}$ as the silicate. However, the discovery that water and secondary minerals in ALH84001, Nakhla and Lafayette have $\Delta^{17} \mathrm{O}$ in excess of the host rock (Karlsson et al., 1992; Farquhar and Thiemens, 2000) implies that not only the carbonates, but also the waters from which they formed were not equilibrated with the parent rocks. Saxton et al. (1998) considered several models for the formation of the ALH84001 carbonates. Models involving isotopic equilibration of fluid with the ALH84001 silicates suggest that the later Mg-rich carbonate formed at $<150{ }^{\circ} \mathrm{C}$ but are difficult to reconcile with the observation of a $\Delta^{17} \mathrm{O}$ excess in the carbonate.

The latter authors also considered a model in which no exchange with silicate takes place and the fluids are derived from a martian hydrosphere and atmosphere, approximate compositions for which were estimated from the Clayton-Mayeda model, with the requirement that it be able to generate the range of $\delta^{18} \mathrm{O}$ values observed in martian carbonates. In this scenario, the earliest carbonates formed from a hot $\left(300-350^{\circ} \mathrm{C}\right)$, water-rich fluid. The later $\mathrm{Mg}$-rich carbonates would have formed at $<90^{\circ} \mathrm{C}$ if the fluid was water-rich, or at higher temperatures if it contained an appreciable mole fraction of $\mathrm{CO}_{2}$.

The trend of increasing $\delta^{18} \mathrm{O}$ from the Ca- to Mg-rich carbonates in ALH84001 is partially consistent with the pattern expected from brine evaporation. Enrichments in $\delta^{18} \mathrm{O}$ are $+6 \%$ due to evaporation of terrestrial sea water and $+17 \%$ o within evaporating brines in areas of low ambient humidity such as salt flats (Lloyd, 1966). However, Saxton et al. (1998) pointed out the isotopic zonation within this carbonate is inconsistent with a single evaporation episode, since $\delta^{18} \mathrm{O}$ becomes approximately constant on reaching the magnesite rim, whilst Rayleigh fractionation would cause $\delta^{18} \mathrm{O}$ to increase more rapidly as deposition proceeded.

\subsection{CARbon, Hydrogen AND Sulphur}

Carbon: Almost all martian meteorites have been analysed by acid dissolution to search for carbonates. Carbonate concentrations are generally low with between $30-60 \mathrm{ppm}$ for the nakhlites (Grady et al., 1997). Carbon isotope results fall into two groups: ALH84001 and the nakhlites all contain ${ }^{13} \mathrm{C}$-enriched carbonates, with $\delta^{13} \mathrm{C}$ ranging from $+10 \%$ o to $+55 \%$ (Carr et al., 1985; Wright et al., 1992; Romanek et al., 1994; Jull et al., 1995), whereas Chassigny and the shergottites have acid-extractable carbon, presumably from the carbonate anion, with $\delta^{13} \mathrm{C}$ ranging from $0 \%$ to $-30 \%$. The most extensive study has been undertaken on ALH84001. Selective dissolution of the carbonate indicates that the early-forming calcium-rich cores of the rosettes are slightly less ${ }^{13} \mathrm{C}$-enriched $\left({ }^{13} \mathrm{C} \sim+39.5 \%\right)$ 
than the later-forming, more Mg-rich mantles, with $\delta^{13} \mathrm{C} \sim+41.8 \%$ (Romanek et al., 1994). Data on calcite from EETA79001 (+6.8\%o, Wright et al., 1988) is more ambiguous and it is possible that this phase is an effect of terrestrial contamination.

The two clear isotopic groups of carbonate are interpreted to represent formation of the minerals in two different environments: the lighter $\delta^{13} \mathrm{C}$ values are from carbonate formed at depth within the martian crust by interaction of primary magmatic fluids with host rock, whereas carbonates in ALH84001 and the nakhlites formed either at, or close to Mars' surface, where fluid exchanged with martian atmospheric $\mathrm{CO}_{2}$ (Carr et al., 1985; Wright et al., 1992; Romanek et al., 1994). The carbon isotopic composition of martian atmospheric $\mathrm{CO}_{2}$ is known to be ${ }^{13} \mathrm{C}$-enriched, but a precise measurement of its $\delta^{13} \mathrm{C}$ is still awaited.

Hydrogen: Several workers have found evidence of a D-enriched reservoir in the martian meteorites. Leshin et al. (1996) analysed $\mathrm{D} / \mathrm{H}$ values in whole rock samples of several martian meteorites and found a wide variation of both $\delta \mathrm{D}$ and water content. The highest $\delta \mathrm{D}$ values were found in the shergottites, with $\delta \mathrm{D}$ up to $+2140 \%$, the water content was $\sim 0.05 \mathrm{wt} \%$. The highest water contents $(0.11-$ $0.39 \mathrm{wt} \%$ ) are in the nakhlites, but these have lower $\delta \mathrm{D}$ (up to $+900 \%$ in a high temperature extraction from Lafayette).

Using an ion microprobe, Sugiura and Hoshino (2000) found an indigenous $\delta \mathrm{D}$ value of $\sim+2000 \%$ o for carbonate and maskelynite in ALH84001, with considerable scatter due to terrestrial contamination. Boctor et al. (1998) also used an ion microprobe to measure $\mathrm{H}$ isotopes in ALH84001 carbonate and phosphate, finding $\delta \mathrm{D}$ up to $+500 \%$ in whitlockite. Saxton et al. (2000a) studied alteration phases in Lafayette - also by ion microprobe - and found $\delta \mathrm{D}$ up to $\sim+1500 \%$. Watson et al. (1994) used an ion microprobe to measure $\mathrm{D} / \mathrm{H}$ in amphibole, biotite and apatite in Chassigny, Shergotty and Zagami, finding variable, but higher than terrestrial, ratios (up to $\sim+4400 \%$ ). They interpreted their results as the result of exchange between low $\mathrm{D} / \mathrm{H}$ primary igneous minerals with a crustal fluid having high $\mathrm{D} / \mathrm{H}$. The high $\mathrm{D} / \mathrm{H}$ enrichments are generally assumed to record atmospheric loss processes (see Section 5 below).

Sulphur: Greenwood et al. $(1997,2000)$ published ion probe determinations of $\delta^{34} \mathrm{~S}$ in sulphides from the nakhlites, Chassigny and the shergottites EETA79001, LEW88516 and QUE94201. Sulphides within the latter 3 shergottites had $\delta^{34} \mathrm{~S}=$ -2.6 to $+3.5 \%$. ALH84001 pyrite, including that associated with carbonate, was +2.0 to $+7.3 \%$. This range is inconsistent with the known sulphur isotopic fractionations associated with bacteria, which produce large enrichments in the light isotope ${ }^{32} \mathrm{~S}$. Nakhla, Governador Valadares and Lafayette had mean $\delta^{34} \mathrm{~S}$ values of $+1.5 \%,+0.7 \%$ and $-3.2 \%$; Chassigny had isotopically light pyrite of -2.9 to $-1.5 \%$. This was interpreted as being the result of progressive oxidation of a fluid, yielding isotopically lighter sulphides with time, which interacted with the nakhlites and Chassigny. Farquhar et al. (2000) also analysed $\delta^{33} \mathrm{~S}$ and $\delta^{36} \mathrm{~S}$ for $\mathrm{SO}_{2}$ and $\mathrm{H}_{2} \mathrm{~S}$ which were mainly released through acid extraction of a range of 
SNCs. The correlations between $\delta^{33} S$ and $\delta^{34} S$ that they identified could not be explained through mass fractionation.

\subsection{Mass-Independent Fractionation Processes}

The variations in $\Delta^{17} \mathrm{O}$ and the correlations between $\delta^{33} \mathrm{~S}$ and $\delta^{36} \mathrm{~S}$ decribed above cannot be explained by processes of mass fractionation alone (e.g. evaporation or condensation). Farquhar and Thiemens (2000) suggested generating an atmospheric reservoir of enhanced $\Delta^{17} \mathrm{O}$ through mass-independent fractionation processes such as exchange between different gas phases (e.g. atomic oxygen and $\mathrm{CO}_{2}$ ). This could then be transferred to crustal fluids and ultimately secondary mineral assemblages in the SNCs. Similarly, Farquhar et al. (2000) suggested that photolysis of atmospheric $\mathrm{SO}_{2}$ and $\mathrm{H}_{2} \mathrm{~S}$ were the most likely explanation for the $\mathrm{S}$ isotopic anomalies. High $\mathrm{D} / \mathrm{H}$ enrichments in meteorites, however, are due to atmospheric loss processes.

Previously, the presence of $\Delta^{17} \mathrm{O}$ excesses was attributed to the influx of cometary material (Karlsson et al., 1992) but as no chondritic material with suitably high $\Delta{ }^{17} \mathrm{O}$ has been identified this idea remains unsubstantiated.

\section{Radiometric Dating: Implications for the Timing of Fluid Activity}

Determining when alteration or evaporation processes occurred is difficult, particularly when many of the alteration products are as fine-grained as those in martian meteorites. There have been only five studies that have tried to address the timing of secondary mineral formation, and those focussed on only two assemblages, the carbonates in ALH84001 and the secondary mineral assemblages in Lafayette.

\subsection{ALH84001 CARBonate}

Three studies of the age of these carbonates have reached three different conclusions. Wadhwa and Lugmair (1996) suggested an age of $1.41 \pm 0.10$ Gyr based on a two-point carbonate-plagioclase Rb-Sr "isochron", and Knott et al. (1997) reported an Ar-Ar age of 3.6 Ga. However, the first was a model age, with inherent uncertainties, and the second was probably actually dating plagioclase (Turner $e t$ al., 1997). The most detailed chronological study of ALH84001 carbonate is that of Borg et al. (1999), who performed selective leaching that gave concordant $\mathrm{Rb}-\mathrm{Sr}$ and $\mathrm{U}-\mathrm{Th}-\mathrm{Pb}$ ages of 3.9-4.0 Gyr. Since the latter number is comparable to most ${ }^{40} \mathrm{Ar}-{ }^{39} \mathrm{Ar}$ ages reported (Turner et al., 1997; Ilg et al., 1997; Bogard and Garrison, 1999; Nyquist et al., 2001) it is likely to be the age of carbonate formation. 


\subsection{The Nakhlite Lafayette}

In a similar approach to that used by Borg et al. (1999), Shih et al. (1998) performed leaching experiments on the nakhlite Lafayette, and obtained a two-point "isochron" from two iddingsite leachates corresponding to an age of $679 \pm 66 \mathrm{Myr}$. Swindle et al. (2000) used a different approach. They extracted individual 1 $20 \mu \mathrm{g}$ samples of alteration products from Lafayette and analyzed them using the $\mathrm{K}$-Ar system. A preliminary experiment had showed that the fine-grained nature of the clay and siderite veins within olivine ('iddingsite') led to a loss of ${ }^{39} \mathrm{Ar}$, the isotope produced by irradiation of potassium, because the recoil energy involved in the neutron capture was sufficient to expel many of the ${ }^{39} \mathrm{Ar}$ atoms from the samples. So instead, they determined $\mathrm{K}$ abundances on each sample via neutron activation analysis, and then measured the amount of argon. There was not a single date at which the ages of their samples clustered. Although many of their samples had demonstrably non-zero ages, the ages ranged from zero to $670 \pm 91 \mathrm{Myr}$. Their oldest age was, within the uncertainty, identical to that of Shih et al. (1998).

\section{Fluid Compositions and Environmental Conditions}

In this section we discuss: (a) ancient water composition and weathering processes (b) the origin of the waters related to evaporation (c) the physical and climatic regime in which they formed.

\subsection{AqueOus WeATHERING AND FLuid COMPOSITIONS}

In a $\mathrm{CO}_{2}$-rich environment where liquid water appeared, it is inevitable that igneous rocks would be weathered, and that the ions so released would eventually be precipitated to maintain mass balance. For instance, glacial melt or groundwater, perhaps released through local igneous activity (Gulick, 1998), would consume atmospheric $\mathrm{CO}_{2}$ to produce carbonic acid. The aqueous weathering processes should produce bicarbonate $\left(\mathrm{HCO}_{3}^{-}\right)$as the main anion, unless significant sulphurous gases are dissolved (for example in subsurface hydrothermal vents), which would cause sulphate to predominate. The bicarbonate molal concentration (i.e. $\mathrm{mol} / \mathrm{kg}$ ) relative to the cation concentration depends on the mole ratios in rock dissolution reactions (Garrels, 1967). The idealized case of the dissolution of iron endmembers, ferrosilite (pyroxene) and fayalite (olivine), by carbonic acid exemplifies weathering under low oxygen conditions:

$$
\begin{aligned}
\mathrm{FeSiO}_{3}+3 \mathrm{H}_{2} \mathrm{O}+2 \mathrm{CO}_{2} & =\mathrm{Fe}^{2+}+2 \mathrm{HCO}_{3}^{-}+\mathrm{Si}(\mathrm{OH})_{4} \\
\mathrm{Fe}_{2} \mathrm{SiO}_{4}+4 \mathrm{H}_{2} \mathrm{O}+4 \mathrm{CO}_{2} & =2 \mathrm{Fe}^{2+}+4 \mathrm{HCO}_{3}^{-}+\mathrm{Si}(\mathrm{OH})_{4}
\end{aligned}
$$

Given more realistic igneous rocks, other cations are released, principally $\mathrm{Mg}^{2+}$, $\mathrm{Ca}^{2+}, \mathrm{K}^{+}$, and $\mathrm{Na}^{+}$. The other main anions, $\mathrm{Cl}^{-}$and $\mathrm{SO}_{4}^{2-}$ are particularly im- 
portant in hydrothermal systems due to the presence of $\mathrm{HCl}$ and $\mathrm{SO}_{2}$ gases. Hydrolyzed silica $\left(\mathrm{Si}(\mathrm{OH})_{4}\right)$ is a product of igneous rock weathering (see above) and silica's fate can take several paths. In a surface zone, some may combine with $\mathrm{Al}$ derived from plagioclase and cations to form clay minerals. Alternatively, silica can precipitate as amorphous silica, which can diagenetically change to quartz or other pure silica forms. Today on Earth, utilization of silica by microscopic organisms greatly suppresses silica concentrations in natural waters. On a non-biological Mars, waters presumably contain silica concentrations either close to temperaturedependent saturation levels or controlled by formation of clays. Smectite-type clays, like those of the nakhlites, sequester silica as well as the group I cations, particularly $\mathrm{K}^{+}$via cation exchange. As silica or clay minerals are early precipitates, they should be associated with other early precipitates like siderite, as seen in Lafayette. Meteorite assemblages affected by evolved waters that percolated into the pore space may be free of silica, which precipitated elsewhere. This might apply to the assemblage in Chassigny, for example. Whereas gibbsite/kaolinite clays form in dilute waters, smectite/illite clays are formed in concentrated solutions (Drever, 1997, p. 282). Consequently, the presence of smectite/illite in SNCs is consistent with solutions concentrated by evaporation in the absence of microbial life.

In general one would expect briny water on Mars to be of type $\mathrm{Na}-\mathrm{Mg}-\mathrm{Fe}-\mathrm{Ca}$ $\mathrm{HCO}_{3}-\mathrm{SO}_{4}-\mathrm{Cl}-\mathrm{H}_{2} \mathrm{O}$, similar to a marine composition except subject to high levels of $\mathrm{CO}_{2}$, making it acidic with high levels of bicarbonate. Water-soluble ions measured by leaching salt deposits directly from Nakhla (Sawyer et al., 2000) provide evidence for this. The Nakhla data suggest that ion concentrations may have been in roughly similar relative proportions to terrestrial seawater, except with a greater relative abundance of $\mathrm{Ca}^{2+}$ and possibly $\mathrm{Mg}^{2+}$. On Earth, the most abundant ions in seawater in order of decreasing concentration are $\mathrm{Cl}^{-}, \mathrm{Na}^{+}, \mathrm{Mg}^{2+}, \mathrm{SO}_{4}^{2-}, \mathrm{Ca}^{2+}$ and $\mathrm{K}^{+}$. Because these ions are so soluble their residence times are long and their proportions are controlled by long-term geochemical processes, such as slow loss to evaporites or hydrothermal sinks at mid-ocean ridges, rather than biology. Smaller components in terrestrial seawater such as $\mathrm{Si}, \mathrm{C}, \mathrm{N}, \mathrm{P}$ and trace elements are largely biologically regulated. The measurements of salts at two locations in Nakhla by Sawyer et al. included the major ions found in terrestrial seawater but not minor components. These measurements are insufficient to deduce the processes that controlled elemental abundances in martian subsurface brines. However, a lower molar ratio of $\mathrm{Mg} / \mathrm{Ca} \sim 0.8-1.5$ in Nakhla salts (Sawyer et al., 2000) compared to a terrestrial value of $\sim 5.2$ suggests hydrothermal activity controlled the brine composition at some point. $\mathrm{Mg}$ tends to be removed from saline water passing through hot rocks and replaced by $\mathrm{Ca}$ (Holland, 1978). In very high temperature hydrothermal exchange with basalt, $\mathrm{K}^{+}$is transferred to saline water but $\mathrm{K}^{+}$is actually depleted in the Sawyer et al. measurements relative to calcium compared to seawater, suggesting moderate temperatures $<100^{\circ} \mathrm{C}$. 


\subsection{Evaporation MOdels}

As discussed in previous sections, it is likely that the secondary minerals are associated with brines. Numerical models of chemical evaporation can help us to understand their nature. In such models, the effect of concentrating the solution by removing water is calculated while maintaining the principles of aqueous chemistry: mass conservation, electroneutrality and equilibria. It is clear, for instance from the oxygen isotopic data discussed previously, that the silicate igneous assemblages did not equilibrate with the fluids. However, gaseous $\mathrm{CO}_{2}$ can rapidly reach equilibrium with fluids. This presumed equilibrium is consistent with the ${ }^{13} \mathrm{C}$-enrichments in carbonate discussed previously. The relatively shallow depth of origin of the nakhlites (estimated at $20-100 \mathrm{~m}$ depth on the basis of comparisons with terrestrial lava flows, Friedman et al., 1999) would also have facilitated brine-atmosphere exchange.

Evaporation models are, however, limited by this assumption of thermodynamic equilibrium and standard models also typically lack iron chemistry. Using a model that did incorporate iron chemistry, Catling (1999) showed that the theoretical sequence of carbonate precipitation under high $\mathrm{CO}_{2}$ conditions follows the sequence of siderite, calcite and then magnesite. An important factor in carbonate precipitation, besides solubility, is the formation of soluble ion pairs or "complexes" in solution. For example, $\mathrm{Fe}^{2+}$, tends to bind to $\mathrm{CO}_{3}^{2-}$ to form the ion pair $\mathrm{FeCO}_{3}^{0}(\mathrm{aq})$ in solution, which suppresses the level of free $\mathrm{CO}_{3}^{2-}$ available and prevents the precipitation of other carbonates prior to siderite. Carbonate solid-solution equilibria (Woods and Garrels, 1992) determine the cationic composition of carbonates. The degree of cation substitution depends on the concentration ratios of cations in solution, e.g. cation displacement between high-Ca siderite and solution is mediated through the equilibrium relation

$\left(a_{\mathrm{CaCO}_{3}} / a_{\mathrm{FeCO}_{3}}\right)_{\text {siderite }}=K\left(a_{\mathrm{Ca}^{2+}} / a_{\mathrm{Fe}^{2+}}\right) a q$

where $a_{i}$ is the activity of species $i$ and $K$ is an equilibrium constant (nonlinear with respect to species ratios). Although such a relationship neglects kinetics, it may help explain the cation composition seen in the meteorite carbonates. A Ca-rich siderite is expected early in evaporation, followed by magnesium-rich carbonate after much of the $\mathrm{Ca}$ and $\mathrm{Fe}$ have been exhausted. After carbonate precipitation, gypsum, anhydrite and halite are expected. This is consistent with the carbonate zoning sequence in ALH84001 and the variation in the mineralogies of alteration products between the 3 nakhlites (Bridges and Grady, 2000), suggesting that thermodynamic models are applicable to modelling of the meteorites' secondary assemblages.

\subsection{Aqueous EnVIRONMENTAL AND ATMOSPHERIC CONDITIONS}

Evaporite mineral precipitation is affected by temperature, $\mathrm{pCO}_{2}, \mathrm{pH}$, and redox conditions, which we discuss in turn. 
Temperature. There is a major difference in the salts that form when water is removed from a brine by evaporation compared to removal by freezing. For example, gypsum or anhydrite followed by halite tends to form when seawater evaporates whereas mirabilite $\left(\mathrm{Na}_{2} \mathrm{SO}_{4} \cdot 10 \mathrm{H}_{2} \mathrm{O}\right)$ followed by hydrohalite $\left(\mathrm{NaCl} \cdot 2 \mathrm{H}_{2} \mathrm{O}\right)$ tends to form in freezing (Herut et al., 1990). The salts identified in the nakhlites, Chassigny and the shergottites suggest that evaporation was the process for water removal rather than concentration and precipitation through freezing. As discussed in previous sections, upper temperatures are more difficult to constrain but point towards initial precipitation $\leq 150^{\circ} \mathrm{C}$ and in a thermodynamic model of progressive evaporation in the nakhlites Bridges and Grady (2000) found that mineral precipitation temperatures of $10-25^{\circ} \mathrm{C}$ were consistent with the evaporite assemblages identified in the 3 meteorites.

$p H$. Salts such as various sodium carbonates tend to appear in highly alkaline brines. These are absent from the meteorites, suggesting that solutions never reached high $\mathrm{pH}$. Instead the presence of iron minerals, such as siderite, containing $\mathrm{Fe}^{2+}$ in the nakhlites and ALH84001, indicate that the precursor fluid had $\mathrm{pH}<7$ in order to carry sufficient $\mathrm{Fe}^{2+}$ cations.

$p \mathrm{CO}_{2}$. The presence of siderite in the nakhlites and ALH84001 suggests high $\mathrm{pCO}_{2}$ conditions. This line of argument follows the same geochemical constraint used in determining $\mathrm{pCO}_{2}$ of the early Earth: for example, $\mathrm{pCO}_{2}$ in the late $\mathrm{Ar}$ chaean is deduced as $<50$ mbar based on the absence of siderite and the presence of hydrous iron silicates in paleosols (Rye et al., 1995). Essentially, in the expected presence of dissolved silica, siderite tends to form at $\mathrm{pCO}_{2}>50-100 \mathrm{mbar}$, whereas hydrous iron silicates will form at lower $\mathrm{pCO}_{2}$ (Catling, 1999). Based on the presence of siderite, this would seem to suggest that the salts in nakhlites and ALH84001 were formed at pCO2 much higher than the current surface pressure on Mars of $\sim 6$ mbar. However, the coexistence of smectites and siderite in the nakhlites could argue for an intermediate level close to $\sim 50$ mbar. The equivalent amount of $\mathrm{CO}_{2}$ locked up in the near surface can be calculated if we assume that typical carbonate amounts in the meteorites represent the whole of Mars. Taking $\sim 0.5 \mathrm{wt} \%$ carbonate, and assuming a crustal density of $3000 \mathrm{kgm}^{-3}, 1000 \mathrm{~m}$ of crust would contain $2.15 \times 10^{18} \mathrm{~kg}$ of carbonate, which, using calcite as the carbonate, is equivalent to $2.15 \times 10^{19} \mathrm{~mol} \mathrm{CO}_{2}$. If this were all released, a $\mathrm{pCO}_{2}$ of $\sim 250$ mbar would result. Alternatively, $200 \mathrm{~m}$ of crust containing this concentration of carbonate would be equivalent to 50 mbar of $\mathrm{CO}_{2}$ being sequestered. Supporting evidence for a martian atmosphere intermittently $>6$ mbar up to geologically recent times is given by gullies identified with very low overlying crater densities and hence of young age (Malin and Edgett, 2000a; Hartmann, 2001). A periodically thicker atmosphere would almost certainly be necessary to stabilise liquid water on the martian surface.

Redox state. The presence of siderite in the nakhlites suggests a weakly reducing environment because of the need to maintain $\mathrm{Fe}^{2+}$ in solution prior to its precipitation in carbonate. Goethite, which is of relatively minor occurrence 
compared to the other secondary minerals, could have been derived from siderite or magnetite as a later oxidation product. In ALH84001, the assemblage pyrite, siderite, magnetite suggests reducing conditions although this evidence may be complicated by the possible association with shock vapourisation, after the initial carbonate precipitation. Reducing conditions are generally consistent with an early Noachian environment which experienced more volcanic outgassing than the later times in martian history in which the younger meteorites' parent rocks formed. This is also a possible explanation for the absence of sulphate in ALH84001, in favour of pyrite.

\subsection{Carbonates in the Martian Crust and Atmospheric Loss PROCESSES}

The martian atmosphere consists of volatiles that were acquired from smaller bodies that either coalesced into the original bulk of the planet or impacted at a later stage. However, Mars later lost volatiles by various physical and chemical processes. Two of the main processes that would have been effective at removing an early thick $\mathrm{CO}_{2}$ atmosphere are: (1) $\mathrm{CO}_{2}$ reacting with surface rocks and water to form carbonates (2) impacts from asteroids or comets blowing away the atmosphere to space Melosh and Vickery (1989). In addition, preferential loss of H, compared to $\mathrm{D}$ occurred due to upper atmospheric loss processes, particularly that of hydrodynamic escape.

Data from Mars Global Surveyor's TES shows that carbonates are not abundant on the present surface and are loosely constrained to $<10 \%$ (Christensen et al., 1998). As calculated in the previous section, the abundance of carbonates in meteorites, if extrapolated globally, suggests the presence of no more than $\sim 0.25$ bar of $\mathrm{CO}_{2}$ in the upper kilometer. Such $\mathrm{CO}_{2}$, if released, would not be sufficient to raise the global mean surface temperature to above freezing (Forget and Pierrehumbert, 1997) although it might contribute to seasonal tropical warming above freezing in combination with obliquity cycles (Haberle et al., 2000). More concentrated subsurface deposits of carbonate sediments are needed to explain sequestration of a thick, early martian atmosphere. Parts of the ancient highlands are composed of meter-scale thick layers (Malin and Edgett, 2000b) and these might include carbonate sediments.

In addition to sequestration of $\mathrm{CO}_{2}$ in carbonate the early atmosphere was thinned by impact erosion (e.g. Melosh and Vickery, 1989). Evidence for this process is given by the striking abundances of radiogenic gases ${ }^{40} \mathrm{Ar}$ and ${ }^{129} \mathrm{Xe}$ (produced after the formation of Mars by the decay of internal ${ }^{40} \mathrm{~K}$ and ${ }^{129} \mathrm{I}$, respectively) relative to the primordial gases ${ }^{36} \mathrm{Ar}$ and ${ }^{132} \mathrm{Xe}$ in the martian atmosphere (Owen, 1992). ${ }^{40} \mathrm{Ar} /{ }^{36} \mathrm{Ar}$ is 296 for Earth and $3000 \pm 500$ for Mars (Owen, 1992). The most probable scenario is that Mars' early atmosphere prior to $\sim 4 \mathrm{Gyr}$ was lost by a combination of subsurface precipitation of carbonates and impact erosion. 
Evidence for isotopically selective atmospheric loss to space is given by $\mathrm{D} / \mathrm{H}$ enrichments found within the meteorites. On present day Mars, the relative loss rates of $\mathrm{D}$ and $\mathrm{H}$ in proportion to their atmospheric density is 0.32 , but fractionation on very early Mars, when there was sufficient hydrogen to cause hydrodynamic escape, may have been in the range $0.8-0.9$ (Zahnle et al., 1990). Hydrodynamic escape is the process whereby extreme fluxes of UV radiation in the early Solar System acted to form outwardly directed fluxes of $\mathrm{H}$ atoms (e.g. Carr, 1996).

Jakosky (1993) modelled the relative loss rates for the different isotopes, loss flux, size of remaining reservoir, and degree of heavy isotope enrichment, which are all quantitatively related. Sugiura and Hoshino (2000) used their ALH84001 results to suggest that the fractional increase in $\mathrm{D} / \mathrm{H}$ of the martian atmosphere from 4.56 to $4 \mathrm{Gyr}$ was 3.0/1.0 or 2000/0\%o. The fraction of original hydrogen remaining on Mars at $4 \mathrm{Ga}$ was estimated at $2.4 \%$. Subsequent fractionation up to recent times must have taken place at a more gradual rate. Atmospheric loss effects are less clear for oxygen, as Farquhar and Thiemens (2000) noted, the lack of a correlation between $\Delta^{17} \mathrm{O}$ and $\delta^{18} \mathrm{O}$ in the SNC secondary minerals is not consistent with this process being the dominant control. However, a loss of $\sim 7 \%$ from the atmospheric oxygen reservoir corresponds to increases of $\sim 20 \%$ in atmospheric $\delta^{18} \mathrm{O}$ and several tenths of a permil in $\Delta^{17} \mathrm{O}$ (Saxton et al., 2000b). Therefore, the $\Delta^{17} \mathrm{O}$ excesses recorded by the secondary minerals probably also include some effects of atmospheric loss in addition to mass-independent fractionation.

\section{Synthesis and Conclusions}

\subsection{Relationship of SNC SeCondary Assemblages to CuRrent MARTIAN SURFACE DEPOSITS}

Most of the martian surface between the poles is partly covered by a mixture of dust and rocks that is inferred to be salt-rich. This partly cemented "soil" is believed to have a fairly homogeneous composition across the planet as a result of redistribution by aeolian activity. Viking and Pathfinder soils have a similar basaltic nature, although the former have higher $\mathrm{SO}_{3}$ and $\mathrm{Cl}$ contents (Newsom et al., 1999; Wänke et al., 2001). The basaltic silicate composition is similar to that of the shergottites.

Thermal emission spectrometry (e.g. at the Pathfinder site) also shows the basaltic nature of the dust and rocks (Bibring and Erard, 2001). In addition, the characteristic ferric absorption edge at $445-800 \mathrm{~nm}$ of the martian surface suggests the presence of palagonite i.e. poorly crystalline ferric oxides of uncertain identity and state of hydration (Morris et al., 2000). Clay and carbonate minerals have not, however, been firmly identified (Banin et al., 1992). Thus, there are significant differences between the weathering products associated with the soil and those of the SNCs. In the latter, ferric oxides form a relatively minor part of the secondary mineral assemblages. The secondary minerals in the meteorites cannot be clearly 
related to the processes associated with the palagonite-type alteration inferred for the global martian soil. Whether the anions in the soil salts originated from brines, gas-solid reactions (Gooding, 1978), acid fog (Banin et al., 1997), hydrothermal fluids (Newsom et al., 1999), or some combination of these processes is not certain. The research on salt minerals in the SNCs does point towards the importance of low temperature brines at or near the martian surface. There is insufficient soil mineralogical data to make direct comparisons to the meteorite data about fluid compositions. However, the low $\mathrm{Mg} / \mathrm{Ca}$ ratio and $\mathrm{K}$ abundances of nakhlite salts may indicate that the prior to evaporation, the brine underwent some hydrothermal exchange $<150^{\circ} \mathrm{C}$ with surrounding igneous rocks.

The possibility of an ancient ocean ( $>3.5 \mathrm{Gyr}$ ) on Mars has been raised (e.g. Carr, 1996; Head et al., 2001). It seems probable that the ocean, if it existed, predated some ancient highland surface based on layering relationships (e.g. Malin and Edgett, 2000b). The evaporites in the nakhlites are later and are better explained by more short-lived events rather than through association with an ocean. For instance, the volume of water in the meteorite parent rocks may have been large, but its presence would have been ephemeral given that evaporite minerals comprise no more than $\sim 1$ vol.\% of martian meteorites and that there is no evidence for prolonged weathering of the surrounding igneous rocks.

\subsection{Formation of the SeCondary Assemblages in SNCS}

The available experimental and phase equilibrium data which are most relevant to the salt minerals in the SNCs suggest relatively low upper temperatures of formation $\left(<150^{\circ} \mathrm{C}\right)$ and, in the case of much of the carbonate, as metastable phases indicating fairly rapid crystallisation, perhaps over days. Siderite may have crystallised at around $25^{\circ} \mathrm{C}$. These temperatures are consistent with the modeling based on stable isotope compositions. Although such an approach has limitations because it is now clear that the secondary assemblages have preserved mass independent fractionations of $\mathrm{H}, \mathrm{S}$ and $\mathrm{O}$ isotopes, the ratios are clearly inconsistent with high temperature equilibration of silicate and carbonate or sulphate minerals. The large fractionation in $\delta^{18} \mathrm{O}$ between the igneous silicate and secondary minerals $\left(>+30 \%\right.$ ) shows that the latter must have formed at $<400{ }^{\circ} \mathrm{C}$. The relatively simple salt assemblages and limited amount of silicate alteration also suggest short-lived pulses of fluid in the parent rocks and a lack of extensive, long-lived hydrothermal systems.

The mineralogical features of the secondary minerals e.g. Ca-rich followed by Mg-rich carbonate, and the sequence of salt mineral crystallisation recorded in the 3 nakhlites are consistent with an origin through brine evaporation. Initial formation from an evaporating brine is the model most consistent with the data on these minerals and such brines were probably acidic and reducing. Some of the secondary minerals (e.g. the siderite located within fractures of Lafayette) are clearly filling fracture/void space. The association of carbonate with feldspathic 
glass, especially in ALH84001 is more ambiguous. There is also firm evidence that high temperature effects, associated with shock, have affected some of the SNCs. In particular, research on a subset of the magnetite grains within the carbonate rosettes of ALH84001 demonstrates the likelihood of shock-induced recrystallisation and partial vapourisation of pre-existing salt assemblages. This process may have partially obscured the nature of the original fluids in the parent rock.

\subsection{Timing And Origin of Aqueous Activity}

The carbonates in ALH84001 appear to be about 3.9 - 4.0 Gyr old. On the other hand, it is still not clear when the weathering products in the nakhlites formed. At least some of them formed several hundred Myr ago. The spread in K-Ar ages could represent partial loss of Ar from the fine-grained samples. However, some clay samples on Earth, with its warmer temperatures, have retained Ar for up to 450 Myr (Dong et al., 1997). Thus, the samples shouldn't have lost their Ar in martian ambient conditions, and Swindle et al. (2000) argued that partial gas loss during processing and irradiation is unlikely. Another alternative is that there is not a single age for these weathering products. If the intimate banding within the Lafayette siderite and clay veins reflected deposition from a sequence of fluids (Vicenzi and Eiler, 1998), there might actually be a wide spread in ages.

The $650-700 \mathrm{Myr}$ formation age implied by both the Rb-Sr model age and the oldest K-Ar age may well be an upper limit, or it might possibly be an average. This means that the alteration occurred and continued long after the formation of the rocks, since their crystallization ages are about $1.3 \mathrm{Gyr}$ (Nyquist et al., 2001). The younger crystallization ages of the shergottites (165-470 Myr, Nyquist et al., 2001) may well indicate more recent fluid activity associated with the secondary mineral assemblages in those meteorites. However, as the distinction between martian and terrestrial salts is not as clearly established as for those in the nakhlites and ALH84001 this important issue remains to be clarified in future work.

A consideration of ALH84001 and Lafayette ages leads to a further implication. Although ALH84001 was in a location favourable to carbonate formation 3.9 Gyr ago, there is little evidence for any other alteration products. The lack of more recent weathering products in ALH84001 argues against a continuously warm and wet martian history. Similarly, as the salt assemblages, in the nakhlites particularly, are highly soluble, their preservation over hundreds of millions of years means it is likely that the fluid activity was not prolonged and recurring but instead took place during one or a few rapid and isolated events. It is possible that sporadic, localised brine migration and evaporation has continued until geologically recent times and is responsible for the gullies seen in recent MOC images on young terrains. The mechanisms associated with the formation of brines and their subsequent evaporation are not certain. An obvious source of energy to melt ice and establish a flow of water is igneous activity. However, if that is the case, the igneous activity that led 
to the alteration of the nakhlites was not associated with the magmatic activity in which the parent rocks formed.

Another process which could have led to ice melting is variation in the solar insolation. This occurred on timescales of $10^{5}-10^{7}$ years as a result of obliquity changes (Bills, 1990; Haberle et al., 2000). Heating alone is not, however, sufficient to explain the formation and nature of the brines from which the SNC secondary minerals probably crystallised. For instance, the siderite and Fe-rich phyllosilicates seen in the nakhlites form together at about $50 \mathrm{mbar}_{\mathrm{pCO}}$ and not the current martian average of 6 mbar. Calculations on the amount of $\mathrm{CO}_{2}$ trapped in the upper few hundred meters of the martian crust in the form of carbonate also suggest that an ancient atmosphere could have had 50-250 mbar $\mathrm{pCO}_{2}$. Therefore thicker atmospheres, with an associated increased chance of liquid water being stabilised were present - at least periodically - during the secondary minerals' formation $\leq 650-700 \mathrm{Myr}$.

\section{Acknowledgements}

JCB and JS are supported by PPARC grants. DC is supported by NASA's Planetary Geology and Geophysics Program. This paper benefited from the reviews of W.K. Hartmann, G. Turner and an anonymous reviewer. E.J. Essene is thanked for a stimulating discussion on SNC secondary mineral compositions.

\section{References}

Anovitz, L.M., and Essene, E.J.: 1987, 'Phase Equilibria in the System $\mathrm{CaCO}_{3}-\mathrm{MgCO}_{3}-\mathrm{FeCO}_{3}$ ', $J$. Petrology 28, 389-414.

Baker, V.R., Carr, M.H., Gulick, V.C., Williams, C.R., Marley, M.S.: 1992, 'Channels and Valley Networks', in H.H. Kieffer, B.M. Jakosky, C.W. Snyder and M.S. Matthews (eds.), Mars, Univ. Arizona Press, Tucson, pp. 493-522.

Baker, L.L., Agenbroad, D.J., and Wood, S.J.: 2000, 'Experimental Hydrothermal Alteration of a Martian Analog Basalt: Implications for Martian Meteorites', Met. Planet. Sci. 35, 31-38.

Banin, A., Clark, B.C. and Wänke, H.: 1992, 'Surface Chemistry and Mineralogy', in H.H. Kieffer, B.M. Jakosky, C.W. Snyder and M.S. Matthews (Eds.), Mars, Univ. Arizona Press, Tucson, pp. 594-625.

Banin, A., Han, F.X., Kan, I. and Cicelsky A.: 1997, 'Acidic Volatiles in the Mars Soil', J. Geophys. Res. 102, 13,341-13,356.

Bell, J.F. III, et al.: 2000, 'Mineralogic and Compositional Properties of Martian Soil and Dust: Results from Pathfinder', J. Geophys. Res. 105, 1721-1755.

Bibring, J.-P., and Erard, S.: 2001, 'The Mars Surface Composition', this volume.

Bills, B.G.: 1990, 'The Rigid Obliquity History of Mars', J. Geophys. Res. 95, 14,137-14,153.

Boctor, N.Z., Wang, J., Alexander, C.M.O'D., Hauri, E., Bertka, C.M. and Fei, Y.: 1998, 'Hydrogen Isotope Studies of Carbonate and Phosphate in Martian Meteorite Allan Hills 84001' Met. Planet. Sci. 33, A18 (abstract).

Bogard, D.D., and Garrison, D.H.: 1999, 'Argon-39-argon-40 "Ages” and Trapped Argon in Martian Shergottites, Chassigny, and Allan Hills 84001', Met. Planet. Sci. 34, 451-473. 
Bogard, D.D., Clayton, R.N., Marti, K., Owen, T., and Turner, G.: 'Isotopic Constraints on the Origin and Evolution of Martian Volatiles', this volume.

Borg, L.E., Connelly, J.N., Nyquist, L.E., Shih, C.-Y., Wiesmann, H., and Reese, Y.: 1999, 'The Age of the Carbonates in Martian Meteorite ALH84001', Science 286, 90-94.

Bradley, J.P., McSween, H.P., and Harvey, R.P.: 1998, 'Epitaxial Growth of Nanophase Magnetite in Martian Meteorite Allan Hills 84001: Implications for Biogenic Mineralization', Met. Planet. Sci. 33, 765-773.

Brass, G.W.: 1980, 'Stability of Brines on Mars', Icarus 42, 20-28.

Brearley, A.J.: 2000, 'Hydrous Phases in ALH84001: Further Evidence for Preterrestrial Alteration and a Shock-induced Thermal Overprint', Proc. $31^{\text {st }}$ Lunar Planet. Sci. Conf., abstract \#1203 (CD-ROM).

Bridges, J.C., and Grady, M.M.: 1999, 'A Halite-siderite-anhydrite-chlorapatite Assemblage in Nakhla: Mineralogical Evidence for Evaporites on Mars', Met. Planet. Sci. 34, 407-416.

Bridges, J.C., and Grady, M.M.: 2000, 'Evaporite Mineral Assemblages in the Nakhlite (Martian) Meteorites', Earth Planet. Sci. Lett. 176, 267-279.

Carr, M.H.: 1996, 'Water on Mars', Oxford Univ. Press, Oxford, 229 pp.

Carr, R.H., Grady, M.M., Wright, I.P., and Pillinger, C.T.: 1985, 'Martian Atmospheric Carbon Dioxide and Weathering-products in SNC Meteorites', Nature 314, 248-250.

Catling, D.C.: 1999, 'A Chemical Model for Evaporites on Early Mars: Possible Sedimentary Tracers of the Early Climate and Implications for Exploration', J. Geophys. Res. 104, 16,453-16,469.

Chatzitheodoridis, E., and Turner, G.: 1990, 'Secondary Minerals in the Nakhla Meteorite' Meteoritics 25, 354 (abstract).

Christensen, P.R., and Moore, H.J.: 1992, ‘The Martian Surface Layer', in H.H. Kieffer et al. (eds.), Mars, Univ. Arizona Press, Tucson, pp. 686-729.

Christensen, P.R., et al.: 1998, 'Results from the Mars Global Surveyor Thermal Emission Spectrometer', Science 279, 1692-1698.

Clayton, R.N., and Mayeda, T.K.: 1988, 'Isotopic Composition of Carbonate in EETA 79001 and its Relation to Parent Body Volatiles', Geochim. Cosmochim. Acta 52, 925-927.

Dong, H., Hall, C.M., Halliday, A.N., and Peacor, D.R.: 1997, 'Laser ${ }^{40} \mathrm{Ar}-{ }^{39} \mathrm{Ar}$ Dating of Microgram-size Illite Samples and Implications for Thin Section Dating', Geochim. Cosmochim. Acta 61, 3803-3808.

Douglas, C., Wright, I.P., and Pillinger, C.T.: 1994, 'A Search for Further Concentrations of Organic Materials in EETA79001', Proc. $25^{\text {th }}$ Lunar Planet. Sci. Conf., 339 (abstract).

Drever, J.I.: 1997, 'The Geochemistry of Natural Waters', Prentice-Hall, London. 436 pp.

Eiler, J.M., Valley, J.W., Graham, C.M., and Fournelle, J.: 1998, 'Geochemistry of Carbonates and Glass in ALH84001', Met. Planet. Sci. 33, A4 (abstract).

Farquhar, J., and Thiemens, M.H.: 2000, 'Oxygen Cycle of the Martian Atmosphere-regolith System: $\Delta^{17} \mathrm{O}$ of Secondary Phases in Nakhla and Lafayette', J. Geophys. Res. 105, 11,991-11,997.

Farquhar, J., Thiemens, M.H., and Jackson, T.: 1998, 'Atmosphere-surface Interactions on Mars: $\Delta^{17}$ O Measurements of Carbonate from ALH84001', Science 275, 1580-1582.

Farquhar, J., Savarino, J., Jackson, T.I., and Thiemens, M.H.: 2000, 'Evidence of Atmospheric Sulphur in the Martian Regolith from Sulphur Isotopes in Meteorites.', Nature 404, 50-52.

Floran, R.J., Prinz, M., Hlava, P.F., Keil, K., Nehru, C.E., and Hinthorne, J.R.: 1978, 'The Chassigny Meteorite: a Cumulate Dunite with Hydrous Amphibole-bearing Melt Inclusions', Geochim. Cosmochim. Acta 42, 1213-1230.

Forget, F., and Pierrehumbert, R.T.: 1997, 'Warming Early Mars with Carbon Dioxide Clouds that Scatter Infrared Radiation', Science 278, 1273.

Forsythe, R.D., and Zimbelman, J.R.: 1995, 'A Case for Ancient Evaporite Basins on Mars', J. Geophys. Res. 100, 5553-5563.

Forsythe, R.D., and Blackwelder, C.R.: 1998, 'Closed Drainage Crater Basins of the Martian Highlands: Constraints on the Early Martian Hydrologic Cycle', J. Geophys. Res. 103, 31,421-31,431. 
Franchi, I.A., Wright, I.P., Sexton, A.S., and Pillinger, C.T.: 1999, 'The Oxygen-isotopic Composition of Earth and Mars', Met. Planet. Sci. 34, 657-661.

Friedman, Lentz, R.C., Taylor, G.J., and Treiman, A.H.: 1999, 'Formation of a Martian Pyroxenite: A Comparative Study of the Nakhlite Meteorites and Theo's Flow', Met. Planet. Sci. 34, 919-932.

Garrels, R.M.: 1967, 'Genesis of Some Ground Waters from Igneous Rocks', in P.H. Abelson (ed.), Researches in Geochemistry Vol. 2, John Wiley, New York, pp. 405-420.

Golden, D.C., Ming, W., Schwandt, C.S., Morris, R.V., Yang, S.V., and Lofgren, G.E.: 2000, 'An Experimental Study on Kinetically-driven Precipitation of Calcium-magnesium-iron Carbonates from Solution: Implications for the Low-temperature Formation of Carbonates in Martian Meteorite Allan Hills 84001.' Met. Planet. Sci. 35, 457-465.

Gooding, J.L.: 1978, 'Chemical Weathering on Mars: Thermodynamic Stabilities of Primary Minerals and Their Alteration Products from Mafic Igneous Rocks', Icarus 33, 483-513.

Gooding, J.L., and Muenow, D.W.: 1986, 'Martian Volatiles in Shergottite EETA79001: New Evidence from Oxidised Sulfur and Sulfur-rich Alumino-silicates', Geochim. Cosmochim. Acta 50, 1049-1059.

Gooding, J.L., Wentworth, S.J. and Zolensky, M.E.: 1988, 'Calcium Carbonate and Sulfate of Possible Extraterrestrial Origin in the EETA79001 Meteorite', Geochim. Cosmochim. Acta 52, 909-916.

Gooding, J.L, Wentworth, S.J., and Zolensky, M.E.: 1991, 'Aqueous Alteration of the Nakhla Meteorite', Meteoritics 26, 135-143.

Grady, M.M., Wright, I.P., and Pillinger, C.T.: 1995, 'A Search for Nitrates in Martian Meteorites', J. Geophys. Res. 100, 5449-5455.

Grady, M.M., Wright, I.P., and Pillinger, C.T.: 1997, 'A Carbon and Nitrogen Isotope Study of Zagami', J. Geophys. Res. 102, 9165-9173.

Greenwood, J.P., Riciputi, L.R., and McSween, H.Y.: 1997, 'Sulfide Isotopic Compositions in Shergottites and ALH84001, and Possible Implications for Life on Mars', Geochim. Cosmochim. Acta 61, 4449-4453.

Greenwood, J.P., Riciputi, L.R., McSween, H.Y., and Taylor, L.A.: 2000, 'Modified Sulfur Isotopic Compositions of Sulfides in the Nakhlites and Chassigny', Geochim. Cosmochim. Acta 64, 11211131.

Gulick, V.C.: 1998, 'Magmatic Intrusions and a Hydrothermal Origin for Fluvial Valleys on Mars', J. Geophys. Res. 103, 19,365-19,388.

Haberle, R.M., McKay, C.P., Schaeffer, J., Joshi, M., Cabrol, N.A. and Grin, E.A.: 2000, 'Meteorological Control on the Formation of Martian Paleolakes', Proc. $31^{\text {st }}$ Lunar Planet. Sci. Conf., abstract \#1509 (CD-ROM).

Hartmann, W.K.: 2001, 'Martian Seeps and Their Relation to Youthful Geothermal Activity', Space Sci. Rev., this volume.

Harvey, R.P., and McSween, H.Y., Jr.: 1996, 'A Possible High-temperature Origin for the Carbonates in the Martian Meteorite ALH84001', Nature 382, 49-51.

Head et al.: 2001, Space Sci. Rev., this volume.

Herut, B., Starinsky, A., Katz, A., and Bein, A.: 1990, 'The Role of Seawater Freezing in the Formation of Subsurface Brines', Geochim. Cosmochim. Acta 54, 13-21.

Holland, H.D.: 1978, 'The Chemistry of the Atmosphere and Oceans', John Wiley, New York, pp. 190-200.

Holland, G., Lyon, I.C., Saxton, J.M., and Turner, G.: 2000, 'Very Low Oxygen-isotopic Ratios in Allan Hills 84001 Carbonates: A Possible Meteoric Component?', Met. Planet. Sci. 35, A76-77 (abstract).

Ilg, S., Jessberger, E.K., and El Goresy, A.: 1997, ${ }^{40} \mathrm{Ar} /{ }^{39}$ Ar Laser Extraction Dating of Individual Maskelynites in SNC Pyroxenite Allan Hills 84001', Met. Planet. Sci. 33, A65 (abstract).

Jakosky, B.M.: 1993, 'Mars Volatile Evolution: Implications of the Recent Measurement of ${ }^{17} \mathrm{O}$ in Water from SNC Meteorites', Geophys. Res. Lett. 20, 1591-1594. 
Jull, A.J.T., Eastoe, C.J., Xue, S., and Herzog, G.F.: 1995, 'Isotopic Composition of Carbonates in the SNC Meteorites ALH84001 and Nakhla', Meteoritics 30, 311-318.

Jull, A.J.T., Eastoe, C.J., and Cloudt, S.: 1997, 'Isotopic Composition of Carbonates in the SNC Meteorites, Allan Hills 84001 and Zagami', J. Geophys. Res. 102, 1663-1669.

Karlsson, H.R., Clayton, R.N., Gibson, E.K., Jr., and Mayeda, T.K.: 1992, 'Water in SNC Meteorites: Evidence for a Martian Hydrosphere', Science 255, 1409-1411.

Kathie, L., Thomas-Keptra, D.A., Bazylinski, D.A., Kirschvink, J.L., Clemett, S.J., McKay, D.S., Wentworth, S.J., Hojatollah, V., Gibson, E.K., Jr., and Romanek, C.S.: 2000, 'Elongated Prismatic Magnetite Crystals in ALH84001 Carbonate Globules: Potential Martian Magnetofossils', Geochim. Cosmochim. Acta 64, 3933-4096.

Knott, S.F., Ash, R.D., and Turner, G.: 1997, ${ }^{40} \mathrm{Ar}-{ }^{39}$ Ar Dating of ALH84001: Evidence for the Early Bombardment of Mars', Proc. 27 th Lunar Planet. Sci. Conf., 765-766 (abstract).

Kring, D.A., Swindle, T.D., Gleason, J.D., and Grier, J.A.: 1998, 'Formation and Relative Ages of Maskelynite and Carbonate in ALH84001', Geochim Cosmochim. Acta 62, 2155-2166.

Leshin, L.A., Epstein, S., and Stolper, E.M.: 1996, 'Hydrogen Isotope Geochemistry of SNC Meteorites', Geochim. Cosmochim. Acta 60, 2635-2650.

Leshin, L.A., McKeegan, K.D., Carpenter, P.K. and Harvey, R.P.: 1998, 'Oxygen Isotope Constraints on the Genesis of Carbonates from Martian Meteorite ALH84001', Geochim. Cosmochim. Acta 62, 3-13.

Lloyd, R.M.: 1966, 'Oxygen Isotope Enrichment of Seawater by Evaporation', Geochim. Cosmochim. Acta 30, 801-814.

Malin, M.C., and Edgett, K.S.: 2000a, 'Evidence for Recent Groundwater Seepage and Surface Runoff on Mars', Science 288, 2330-2335.

Malin, M.C., and Edgett, K.S.: 2000b, 'Sedimentary Rocks of Early Mars', Science 290, 1927-1937.

McKay, D.S., Gibson, E.K., Jr., Thomas-Keptra, K.L., Vali, H., Romanek, C.S., Clemett, S.J., Chiller, X.D.F., Maechling, C.R., and Zare, R.N.: 1996, 'Search for Past Life on Mars: Possible Biogenic Activity in Martian Meteorite ALH84001', Science 273, 924-930.

McSween, H.Y., and Harvey, R.P.: 1998, 'An Evaporation Model for the Formation of Carbonates in the ALH84001 Martian Meteorite', Intern. Geol. Rev. 40, 774-783.

Melosh, H.J., and Vickery, A.M.: 1989, 'Impact Erosion of the Primordial Atmosphere of Mars', Nature 338, 487-489.

Mittlefehldt, D.W.: 1994, 'ALH84001, a Cumulate Orthopyroxenite Member of the Martian Meteorite Clan', Meteoritics 29, 214-221.

Moersch, J.E., Farmer, J., and Hook, S.J.: 2000, 'Detectability of Martian Evaporites - Terrestrial Analog Studies with MASTER Data', Proc. $31^{\text {st }}$ Lunar Planet. Sci. Conf., abstract \#2054 (CDROM).

Moore, H.J., Bickler, D.B., Crisp, J.A., Eisen, H.J., Gensler, A., Haldemann, A.F.C., Matijevic, J.R., Reid, L.K. and Pavlics, F.: 1999, 'Soil-like Deposits Observed by Sojourner, and Pathfinder Rover', J. Geophys. Res. 104, 8729-8746.

Morris, R.V., et al.: 2000, 'Mineralogy, Composition, and Alteration of Mars Pathfinder Rocks and Soils: Evidence from Multispectral, Elemental, and Magnetic Data on Terrestrial Analogue, SNC Meteorite, and Pathfinder Samples', J. Geophys. Res. 105, 1757-1817.

Newsom, H.E., Hagerty, J.J., and Goff, F.: 1999, 'Mixed Hydrothermal Fluids and the Origin of the Martian Soil', J. Geophys. Res. 104, 8717-8728.

Nyquist, L.E., Bogard, D.D., Shih, C.-Y., Greshake, A., Stöffler, D., and Eugster, O.: 2001, 'Ages and Geologic Histories of Martian Meteorites', Space Sci. Rev., this volume.

Owen, T.: 1992, The Composition and Early History of the Atmosphere of Mars, in H.H. Kieffer et al. (eds.), Mars, Univ. Arizona Press, Tucson, pp. 818-834.

Reid, A.M., and Bunch, T.E.: 1975, The Nakhlites, Part II. Where, When and How?', Meteoritics 10, 317-324. 
Romanek, C.S., Grady, M.M., Wright, I.P., Mittlefehldt, D.W., Socki, R.A., Pillinger, C.T., and Gibson, E.K., Jr.: 1994, 'Record of Fluid-rock Interactions on Mars from the Meteorite ALH84001', Nature 372, 655-657.

Romanek, C.S., Perry, E.C., Treiman, A.H., Sockim, R.A., Jones, J.H., and Gibson, E.K.: 1998, 'Oxygen Isotopic Record of Silicate Alteration in the Shergotty-Nakhla-Chassigny Meteorite Lafayette', Met. Planet. Sci. 33, 775-784.

Ruff, S.W., et al.: 2000, 'Mars “White Rock” Feature Lacks Evidence of an Aqueous Origin', Proc. $31^{\text {st }}$ Lunar Planet. Sci. Conf., abstract \#1945 (CD-ROM).

Russell, M.J., Ingham, J.K., Zadef, V., Maktav, D., Sunar, F., Hall, A.J., and Fallick, A.E.: 1999, 'Search for Signs of Ancient Life on Mars: Expectations from Hydromagnesite Microbialites, Salda Lake, Turkey', J. Geol. Soc. 156, 869-888.

Rye, R., Kuo, P.H., and Holland, H.D.: 1995, 'Atmospheric Carbon Dioxide Concentration Before 2.2 billion Years Ago', Nature 378, 603-605.

Sawyer, D.J., McGehee, M.D., Canepa, J., and Moore, C.B.: 2000, 'Water Soluble Ions in the Nakhla Martian Meteorite', Met. Planet. Sci. 35, 743-747.

Saxton, J.M., Lyon, I.C., and Turner, G.: 1998, 'Correlated Chemical and Isotopic Zoning in Carbonates in the Martian Meteorite ALH84001', Earth Planet. Sci. Lett. 160, 811-822.

Saxton, J.M., Lyon, I.C., and Turner, G.: 2000a, 'Ion Probe Studies of Deuterium/hydrogen in the Nakhlite Meteorites', Met. Planet. Sci. 35, A142-A143.

Saxton, J.M., Lyon, I.C., Chatzitheodoridis, E., and Turner, G.: 2000b, 'Oxygen Isotopic Composition of Carbonate in the Nakhla Meteorite: Implications for the Hydrosphere and Atmosphere of Mars', Geochim. Cosmochim. Acta 64, 1299-1309.

Scott, E.R.D.: 1999, 'Origin of Carbonate-magnetite-sulfide Assemblages in Martian Meteorite ALH84001', J. Geophys. Res. 104, 3803-3813.

Scott, E.R.D., Yamaguchi, A., and Krot, A.N.: 1997, 'Petrological Evidence for Shock Melting of Carbonates in the Martian Meteorite ALH84001', Nature 387, 377-379.

Shih, C.-Y., Nyquist, L.E., Reese, Y., and Wiesmann, H.: 1998, 'The Chronology of the Nakhlite, Lafayette: Rb-Sr and Sm-Nd Isotopic Ages', Proc. $29^{\text {th }}$ Lunar Planet. Sci. Conf., abstract \#1145 (CD-ROM).

Steele, A., Goddard, D.T., Stapleton, D., Toporski, J.K.W., Peters, V., Bassinger, V., Sharples, G., Wynn-Williams, D.D., and McKay, D.S.: 2000, 'Investigations Into an Unknown Organism on the Martian Meteorite Allan Hills 84001', Met. Planet. Sci. 35, 237-242.

Stöffler, D., Ostertag, R., Jammes, C., Pfannschmidt, G., Sen Gupta, P.R., Simon, S.B., Papike, J.J., and Beauchamp, R.H.: 1986, 'Shock Metamorphism and Petrography of the Shergotty Achondrite', Geochim. Cosmochim. Acta 50, 889-903.

Sugiura, N., and Hoshino, H.: 2000, 'Hydrogen Isotopic Composition of Allan Hills 84001 and the Evolution of the Martian Atmosphere', Met. Planet. Sci. 35, 373-380.

Swindle, T.D., Treiman, A.H., Lindstrom, D.J., Burkland, M.K., Cohen, B.A., Grier, J.A., Li, B., and Olson, E.K.: 2000, 'Noble Gases in Iddingsite from the Lafayette Meteorite: Evidence for Liquid Water on Mars in the Last Few Hundred Million Years', Met. Planet. Sci. 35, 107-115.

Treiman, A.H.: 1985, 'Amphibole and Hercynite Spinel in Shergotty and Zagami: Magmatic Water, Depth of Crystallization, and Metasomatism', Meteoritics 20, 229-243.

Treiman, A.H.: 1995, 'A Petrographic History of Martian Meteorite ALH84001: Two Shocks and an Ancient Age', Meteoritics 30, 294-302.

Treiman, A.H.: 1998a, 'The History of Allan Hills 84001 Revised: Multiple shock events', Met. Planet. Sci. 33, 753-764.

Treiman, A.H.: 1998b, 'Amphiboles in More Martian Meteorites: Elephant Moraine 79001B, Elephant Moraine 79001X, and Lewis Cliff 88516', Met. Planet. Sci. 33, A156 (abstract).

Treiman, A.H., Barrett, R.A., and Gooding, J.L.: 1993, 'Preterrestrial Alteration of the Lafayette (SNC) Meteorite', Meteoritics 28, 86-97. 
Turner, G., Knott, S.F., Ash, R.D., and Gilmour, J.D.: 1997, 'Ar-Ar Chronology of the Martian Meteorite ALH84001: Evidence for the Timing of the Early Bombardment of Mars', Geochim. Cosmochim. Acta 61, 3835-3850.

Valley, J.W., Eiler, J.M., Graham, C.M., Gibson, E.K., Romanek, C.S., and Stolper, E.M.: 1997, 'Low-temperature Carbonate Concretions in the Martian Meteorite ALH84001: Evidence from Stable Isotopes and Mineralogy', Science 275, 1633-1637.

Vicenzi, E.P., and Eiler, J.: 1998, 'Oxygen-isotopic Composition and High Resolution Secondary Ion Mass Spectrometry Imaging of Martian Carbonate in Lafayette Meteorite', Met. Planet. Sci. 33, A159-A160 (abstract).

Wadhwa, M., and Crozaz, G.: 1995, 'Constraints on the Rare Earth Element Characteristics of Metasomatizing Fluids in the Martian Meteorite ALH84001' Proc. $26^{\text {th }}$ Lunar Planet. Sci. Conf., 1451-1452 (abstract).

Wadhwa, M., and Lugmair, G.W.: 1996, 'The Formation Age of Carbonates in ALH84001', Met. Planet. Sci. 31, A145 (abstract).

Wadhwa, M., Lentz, R.C.F., McSween, H.Y., and Crozaz, G.: 2000, 'Dar al Gani 476 and Dar al Gani 489, Twin Shergottites from Mars', Proc. $31^{\text {st }}$ Lunar Planet. Sci. Conf., abstract \#1413 (CD-ROM).

Wänke, H., Brückner, J., Dreibus, G., Rieder, R., and Ryabchikov, I.: 2001, 'Chemical Composition of Rocks and Soils at the Pathfinder Site', this volume.

Warren, P.H.: 1998, 'Petrologic Evidence for Low-temperature, Possibly Flood Evaporitic Origin of Carbonates in the ALH84001 Meteorite', J. Geophys. Res. 103, 16,759-16,773.

Watson, L.L., Hutcheon, I.D., Epstein, S. and Stolper, E.M.: 1994, 'Water on Mars: Clues from D/H and Water Contents of Hydrous Phases in SNC Meteorites', Science 265, 85-90.

Wentworth, S.J., and Gooding, J.L.: 1994, 'Carbonates and Sulfates in the Chassigny Meteorite: Further Evidence for Aqueous Chemistry on the SNC Parent Planet', Meteoritics 29, 861-863.

Wentworth, S.J., and Gooding, J.L.: 2000, 'Weathering and Secondary Minerals in the Martian Meteorite Shergotty', Proc. $31^{\text {st }}$ Lunar Planet. Sci. Conf., abstract \#1888 (CD-ROM).

Woods, T.L., and Garrels, R.M.: 1992, 'Calculated Aqueous Solution Solid-solution Relations in the Low Temperature System CaO-MgO-FeO- $\mathrm{CO}_{2}-\mathrm{H}_{2} \mathrm{O}$ ', Geochim. Cosmochim. Acta 56, 3031 3043.

Wright, I.P., Grady, M.M., and Pillinger, C.T.: 1988, 'Carbon, Oxygen and Nitrogen Isotopic Compositions of Possible Martian Weathering Products in EETA79001.' Geochim. Cosmochim. Acta 52, 917-924.

Wright, I.P., Grady, M.M., and Pillinger, C.T.: 1992, 'Chassigny and the Nakhlites: Carbon Bearing Components and Their Relationship to Martian Environmental Conditions', Geochim. Cosmochim. Acta 56, 817-826.

Zahnle, K., Kasting, J.F., and Pollack, J.B.: 1990, 'Mass Fraction of Noble Gases in Diffusion-limited Hydrodynamic Escape', Icarus 84, 502-527.

Address for correspondence: J.C. Bridges, Department of Mineralogy, Natural History Museum, Cromwell Road, London SW7 5BD, UK; (j.bridges@nhm.ac.uk) 